Made available courtesy of Cambridge University Press: http://www.cambridge.org ***Reprinted with permission. No further reproduction is authorized without written permission from Cambridge University Press. This version of the document is not the version of record. Figures and/or pictures may be missing from this format of the document.***

\title{
Goals and methods: The study of development versus partitioning of variance
}

Douglas Wahlsten

Department of Psychology, University of Alberta, Edmonton, Alberta, Canada T6G 2E9

Electronic mail userdwa@ualtamts.bitnet

The central thesis of the target article is that the statistical power of two-way analysis of variance to detect certain 
kinds of interaction or nonadditivity is substantially less than the power to detect main effects in the same circumstances. Among the 26 commentators on this article, 24 express agreement in one form or another with this claim. This is gratifying, but not entirely surprising, because the point had been made some time ago by Neyman (1935) and has been reiterated from time to time in the literature. It is apparent that several commentators (Dawes, Denenberg, Maxwell) had already addressed this matter in their teaching and scholarly studies, if not in print. It must be admitted, however, that many researchers in the behavioral and brain sciences were not aware of the extent of the difficulty, or of its history. The target article demonstrates the magnitude of the difference in power specifically for a multiplicative model and several other realistic alternatives to additivity. This should help to create an awareness of the problem among readers, but, as Lipp predicts and several commentators confirm, it is not likely to dissuade the advocates of heritability analysis from practising their art. The various commentaries illustrate with great clarity how the different perspectives and goals of investigators condition their attitudes towards statistical methods.

1. Questions of power and light. Several commentators argue persuasively that the problem of low power could be studied or expressed differently and perhaps more simply.

Dawes demonstrates clearly how the linear contrast for interaction in a $2 \times 2$ design can help us compare different types of interaction and their main effects. Using this approach with the $Y=(\mathrm{jh})(\mathrm{ke})$ model when $\mathrm{h}=\mathrm{e}=1$, the means would be

\begin{tabular}{l|l|l|} 
& $\mathrm{H}_{1}$ & $\mathrm{H}_{2}$ \\
\cline { 2 - 3 } $\mathrm{E}_{1}$ & 1 & 2 \\
\cline { 2 - 3 } $\mathrm{E}_{2}$ & 2 & 4 \\
\cline { 2 - 3 } & &
\end{tabular}

The contrast for the strain difference would be $(4+2)-(2$ $-1)=3$ and for $H \times E$ interaction would be $(4-2)-(2$ $-1)=1$. This humble example does get at the essence of the matter. I believe (with Lachenbruch 1988) the sample size required to achieve a specified degree of power should be inversely proportional to the square of the contrast, which implies that about nine times as many observations per cell will be needed to detect the multiplicative interaction compared to the main effect (see Wahisten [unpublished]). The relative sample sizes indicate the additional quantity of subjects, time, and grant funds needed to detect real nonadditivity in the data. Dawes also presents valuable advice on the proper way to code interactions in multiple regression analysis.

Denenberg expresses the problem in terms of the correlation between group means across the various treatments. When two rat strains respond the same way to several environments, the correlation will be very migh, and the mean square for interaction according to his equation (3) will approach zero. If there is no correlation, 18 When one strain is strongly affected by the treatment and the other shows no change at all, interaction should be substantial: This should apply to the scenario por- trayed by Kline, in which one main effect is much larger than the other but the interaction is significant. If they respond in opposite ways, yielding a negative correlation, interaction should predominate. Denenberg suggests that the power of the test of interaction will be lower than for the main effects only when the correlation is positive. However, my example of $Y=a+b X$, Case 1, in Figure 2 (a) of the target article suggests that the power to detect the interaction can be lower than for the main effect when the correlation is negative. Denenberg's formula (3) applies to sample data, whereas power calculations require population parameters derived from a model specified a priori. As suggested by Maxwell, the respective degrees of freedom are also part of the story; that is, the number of strains and treatment conditions as well as the correlation across treatments must be considered.

Maxwell casts further light on the subject by showing that the ordinal versus disordinal distinction between kinds of interactions does inform us about relative power in the specific instance of the $2 \times 2$ design when the degrees of freedom for main effects and interaction are identical. I agree with his contention that, for larger designs, the power of the test of interaction can be increased by using a planned contrast to test for an optimal interaction subeffect. Presuming that the test is planned before peeking at the results, this is feasible only when one has a good idea about the nature of the biological or psychological processes involved. Those aiming simply to partition variance may be stuck with the feeble global $\mathbf{F}$ test of interaction.

Cicchetti proposes that computer simulation be used to explore further aspects of the problem which may not be amenable to the technique I used. Chiszar, \& Gollin and Maxwell make a similar suggestion. The Soper et al. (1988) and Adams et al. (1985) studies mentioned by Cicchetti as well as the study by Heth et al-(1989) provide excellent examples of the utility of this approach. When I first presented a paper on this topic at the Behavior Genetics Association meeting in Minneapolis (Wahlsten 1987a), I used a Monte Carlo program written in " $C$ " to obtain a quick estimate of relative power for a $5 \times 5$ design. Subsequently, I adopted the algebraic method because of its greater apparent elegance, but I acknowledge that there will be trouble extending it to situations where a computer simulation would work readily. For example, Chiszar \& Gollin point out that ANOVA main effects and Type I errors may be relatively robust against nonnormality or heterogeneity of variance, but that these issues have not been well evaluated with regard to interaction or type II errors. These and other violations of assumptions could be incorporated into a Monte Carlo study, with due attention to the properties of the random number generator (Press et al. 1988, Chap. 7).

Several commentators recommend alternative approaches to the standard ANOVA rather than increasing sample size. Bullock maintains that the larger $\mathbf{n}$ does not solve the root problem afflicting behavior genetics; he calls for the use of consistency checks on the results of ANOVA and better training of psychologists in applied mathematics. His remedies have considerable merit. I contend that if one wishes to rely on the results of ANOVA to assess interaction, larger samples ought to be used. At the same time, in section 12 of the target article I note that the global F-test is not necessarily the best 
solution. Carlier \& Marchaland propose Bayesian inference as a cure for some of the shortcomings of ANOVA, because decisions about significance are contingent upon effect size. Bayesian methods also incorporate explicit statements about the investigators' beliefs (Berger \& Berry 1988) and thereby discourage impetuous acceptance of the null hypothesis. Both consistency checks and Bayesian inference can help to avoid the worst pitfalls of ANOVA, as can the likelihood ratio test advocated by Marler (1980) as well as by McGuffin \& Katz. Goodall informs us of a forthcoming volume on ANOVA which addresses these issues directly, so that our minds can remain open to new procedures. However, I doubt that any mathematical method can obviate the need for larger samples when one is seeking to make a finer discrimination or to test for subtler effects such as multiplicative interaction. Better math can increase efficiency and reduce the drain on scarce research funds, but this cannot equate the sensitivities of even the best test to large and small effects.

Of course, extending the range of circumstances to achieve higher power, as suggested by Henderson and by Van Noordwijk, could preclude the need for larger samples if the experiment allows for this; but the power of ANOVA will still be lower for the interaction than the main effects if $\mathbf{H}$ and $\mathbf{E}$ are multiplicative.

2. Generallty of the model. Two commentators (Kempthorne, Schönemann) assert that a random-effects rather than a fixed-effects model should have been used. Although neither claims definitively that the problem of low power to detect interaction would disappear with a random-effects model, they suggest that the central thesis is not established beyond doubt in the target article. Neither elaborates reasons why one model is preferable. Having reconsidered the question, I still think the fixed effects model is appropriate for the present purpose. Furthermore, the central conclusion would not be altered by using the random effects model; on the contrary, the power to detect heredity by environment $(H \times \mathbf{E})$ interaction would be even lower than with a fixed-effects model.

The main issue in choosing the model is the generality of the results. With fixed effects involving, for example, two inbred mouse strains reared in two environments, the results must be considered specific to the strains and environments actually studied. On the other hand, if several genotypes are sampled randomly from a larger population of diverse genotypes, as proposed by Kempthorne, and several rearing environments are similarly chosen, then results can legitimately be applied to the entire population.

Let us ask: How do the users of two-way factorial designs actually choose their animal subjects and levels of environment, and what sorts of generalizations do they make? As Henderson confirms, when rodents or flies are the subjects, it is customary and wise to choose strains likely to have extreme scores or, as advocated by Ward (1985), known to differ greatly at a large number of genetic loci. It is common practice to test a wide variety of strains and then choose two with extreme scores for further genetic analysis (Bauer \& Sokolowski 1985; Wimer \& Wimer 1982). Alternatively, selective breeding may be used to produce a maximum difference in behav- ior (Brush et al. 1985; Ricker \& Hirsch 1988). Environments are typically chosen to yield a large difference in outcome, and care is exercised to restrict conclusions to the conditions actually observed.

The $2 \times 2$ design in particular inherently lacks generality. Even if the uninitiated were to choose strains and levels of environment entirely at random with the most inscrutable of computer programs, I cannot imagine even one experienced researcher accepting the results as representative of a wide range of strains and treatments.

When two- and three-way factorial designs are used, relatively few levels of each factor are commonplace. It is not at all surprising therefore that tabulations of power of ANOVA, such as those by Cohen (1988) as well as Rotton and Schönemann himself (1978), often restrict attention to fixed effects models.

If the design of the experiment does indeed warrant use of a random effects model, the power of the test of $\mathrm{H}$ $\times \mathrm{E}$ interaction can be readily estimated. Koele (1982) considers a two-way design where the significance of the interaction term is tested against the error mean squares using the critical ratio $F_{c}$. If the true variance of interaction effects is $\sigma_{A B}^{2}$ and the error variance is $\sigma_{\xi}^{2}$, the result is

$$
\text { Power }=\operatorname{Pr}\left\{\mathrm{F} \geq \mathrm{F}_{\mathrm{e}} /\left(1+n \sigma^{2}{ }_{\mathrm{AB}} / \sigma_{\mathrm{e}}^{2}\right)\right\} \text {. }
$$

In the target article I follow Cohen's convention for effect size $f$ as the ratio of standard deviations. For two-way interaction $\sigma_{\mathrm{AB}} / \sigma_{\mathrm{E}}=\mathrm{f}_{\mathrm{I}}$. Thus,

$$
\text { Power }=\operatorname{Pr}\left\{\mathrm{F} \geq \mathrm{F}_{\mathrm{c}} /\left(1+\mathrm{nf}_{\mathrm{I}}^{2}\right)\right\} \text {. }
$$

Although Kempthorne suggests that the power of the interaction effect in a random effects design can be assessed with Tang's tables of the noncentral $F$ distribution, Scheffé (1959, p. 227), Koele (1982) and Schönemann argue that the central $F$ distribution is appropriate in this situation. Let us now compare the power of the same interaction effect size estimated (a) as in Cohen (1988) under the fixed effects model with the noncentral $F$ distribution, as done in the target article, and (b) under the random effects model as in Koele (1982) with the central $F$ distribution. Let there be five levels each of heredity and environment with 10 subjects in each of 25 groups, and let $\alpha=0,05$. The power to detect $\mathbf{H} \times \mathbf{E}$ interaction is generally lower under the random effects model.

The test of main effects under a random effects model is properly done with respect to the interaction mean squares if the interaction is indeed significant. This outcome will have devastating consequences for the power of tests of main effects; but it will occur rarely because of low power and is not pertinent to the theme of the target article, where the focus is on situations in which there really is interaction but the researcher concludes that there is none. In such a situation, one may decide to test the main effects against the error term, a step to be taken with trepidation (Hays 1988) although it is often taken in practice. Suppose the main effect size for heredity or a strain difference is 0.4 in a $5 \times 5$ experiment with 10 mice per group. As shown in the target article, under a fixed effects model the power to detect the main effect will be greater than $99 \%$, whereas with random effects it will be $46 \%$. Multiplicative interaction with equally spaced levels of $\mathrm{H}$ and $\mathrm{E}$ will have a corresponding effect size of 0.189 , which will yield power of $36 \%$ under a fixed effects 
Table 1 Power (\%) of $5 \times 5$ ANOVA to detect interaction winder fixed effects and random effects models with same effect sizes when $n=10$ and $\alpha=0.05$.
Interaction Effect size

\section{0,05}

0.10

0.20

0.30

0.10 pthorne (1978) of prevalent misconceptions is most informative, as is the review of additional criticisms by Dudley and Hirsch. Let me assure these astute commentators and $B B S$ readers that $I$ do not think $H \times E$ interaction poses the only challenge to heritability analysis. The twoway factorial design using inbred strains minimizes covariance, as Crusio notes; and omitting such an effect from the ANOVA model can be justified in the target article and in the laboratory when an experiment of this kind is done.

Kline questions the relevance of studies of nonhuman animals to humans because "man alone" has a strong influence on the environment. My reading of behavioral ecology suggests otherwise. Bullock states that humans are the "most extreme" in this respect but are not alone. The very essence of animal behavior is transformation and creation of the environment, as should be apparent in the cycle of ingestion, digestion, and excretion, as well as in the phenomena of habitat selection, burrowing or nest construction, etc. Chiszar \& Gollin stress the "interdefinition of genome, organism, and ecosystem." Lewontin (1982) also explains very well the interpenetration of the organism and its environment. In the laboratory we attempt to restrict the operation of some of these processes in order to simplify and analyze mechanisms. Just as Mendel needed a uniform plot of ground to reveal laws of genetic transmission, so is precise control of heredity and environment in the lab helpful to document interaction. In society at large we should expect to find both Mendelian inheritance and heredity-environment interaction, and we should be skeptical of any model which presumes the presence of one but the absence of the other.

Dudley and McGuffin \& Katz propose that a realistic model ought to incorporate interactions between genes at different loci (epistasis) as well as between genes and environment. This is especially important when one wishes to analyze the components of global heredity, which can only be done with cross-breeding schemes. Comparing several inbred strains varies heredity but cannot further elucidate its mechanisms. As mentioned by Crow, there is abundant evidence that the consequences of genes at one locus depend on genotype at other loci. This has been amply demonstrated for mouse pigmentation (Lamoreux \& Pendergast 1987), obesitydiabetes (Coleman 1981), and brain development (Billings-Gagliardi \& Wolf 1988; Kerner \& Carson 1986), and evidence is sometimes found for behavior (Bateson \& D'Udine 1986). When one is attempting to understand the dynamics of development, these phenomena can be most informative. Contrary to the claim by Crow that inbreeding reduces error variation, inbreeding often increases phenotypic variance above the level seen in $F_{1}$ hybrids (Hyde 1973; Palmer \& Strobeck 1986), and this may very well stem from epistatic interaction.

If a more complex model were formulated to take account of several kinds of covariance and gene-gene interaction as well as heredity-environment interaction, the sensitivity of the test of interaction would very probably be extremely low - if a decisive test could be formulated at all for humans. The $2 \times 2$ test proposed by Plomin et al. (1977) is not valid because it classifies adoptees by phenotype of biological parents rather than the adoptees' own genotypes. Any test of $\mathrm{G} \times \mathrm{E}$ interaction must 
involve replicated genotypes reared in different environments. Otherwise, innumerable combinations of genes and environments can yield the same phenotypic outcome. The target article concentrated on the $2 \times 2$ test of interaction because it is advocated by well-known spokesmen for behavior genetics. The point is made that even if one considers this test credible for humans (which I do not) the power is usually so low that any negative results must be inconclusive. The great confidence with which some researchers proclaim the absence or rarity of $\mathrm{H} \times \mathrm{E}$ interactions is not warranted by the shaky ladder of dubious assumptions on which they stand.

4. Focus on development. The target article contrasted two research agendas: the study of development and the partitioning of variance. The commentaries indicate that this dichotomy was no figment of my imagination. Developmentalists have very little interest or faith in assigning definite percentages of variance to contributing causes. Inferential statistics may be used as an aid to decision making, but the statistical models are not reified the way they so often are in behavior genetics. The developmental perspective in no way denies the importance of genes or espouses "genetic nihilism," as implied by Henderson. Interactionism advances beyond the sterile naturenurture dichotomy inherent in the ubiquitous $\mathrm{G}+\mathrm{E}$ of human behavior genetics.

Bookstein stresses that "the scientist needs to know the form of $f$," the function relating heredity and environment. Bullock says we need "quantitative models of actual processes." Cheverud wants us to improve the genetic analysis of development by generating "developmental models which would help guide the analysis." Chiszar \& Gollin seek "the adduction of the organizing principles that mediate development." Crusio urges the use of genetic techniques for studying causal relationships between brain and behavior. Harrington instructs us that "for explanatory purposes a model must be logically and theoretically, not empirically, based," and he shows how a developmental perspective can specify the proper order of entry of variables into a multiple regression equation. Lipp argues that "understanding the target" of gene action should precede studies of how genes affect it. Maxwell stresses the importance of developing a "correct model of the phenomenon under study." Nyborg is after precise knowledge about "the character, mechanisms, and locus of action" of causes, and he is not satisfied with gene effects that are "assumed rather than localized and specified."

Explorations of physiologically real interactions can lead to noteworthy progress in our understanding of ontogeny (e.g. Beardsley 1988; Ingham 1988; Vardimon et al. 1988; Yeakley et al, 1987). The hypotheses proposed by Lipp and Nyborg exemplify the fruitfulness of a developmental perspective. Lipp proposes that later acting "psychogenes" will tend to affect neural systems at a higher hierarchical level, and that single gene effects are more likely to be observed on complex behaviors. This approach to behavior genetics is meaningful for the developmentalist. Nyborg envisions bidirectional relations in a way that informs rather than offends the psychologist interested in chemistry and behavior. Dynamic nonlinear models of gene action in neuroendocrinology illustrate the merits of a physiological and psychological interactionist approach (see Nyborg).

Crow draws a distinction between $\mathrm{H} \times \mathrm{E}$ interaction which can and cannot be removed by a monotonic trans. formation and regards only the latter as "real." However, to the developmentalist the judgment of which is real and which is mere appearance cannot be made simply from mathematical form. One must know how things actually work. Only then can certain functional relationships be regarded as trivial instances of apparent interaction, while others are seen as profound. Likewise, the merits or demerits of the idea mentioned by Coodnight and championed by Falconer (1981) - that gene-environment interaction can be subsumed under genetic correlation as the proportion of genes acting in common in two environments to determine two measures - must be decided by molecular biology, not by population genetics. I, for one, very much doubt the veracity of this hypothesis because the calculations assume additivity of genes and environment within the corresponding environments, while allowing qualitative differences between environments.

Plomin's contention that main effects and interactions are "independent" makes no sense from a developmental perspective (Lewontin 1974; Oyama 1985). It is also mathematically wrong for the case of a random effect model that ought to be applied to a human population. The two-way fixed effects ANOVA we use in laboratory studies will separate the total variance into four separate piles even when the true functional relationship is multiplicative. Main effects are defined as being additive, and interaction is defined as the departure from additivity. If there is clearly significant departure from additivity, the null hypothesis of additivity should be rejected outright. Then there is no additivity at all and main effects are mere artifacts of the algebra. If $\mathrm{H}$ and $\mathrm{E}$ are multiplicative, then $100 \%$ of the relationship is $\mathrm{H} \cdot \mathrm{E}$ and none of it is additive.

Plomin's claim that in the target article the finding of interaction had no effect on the main effects is mistaken. As explained in section $7, I$ arbitrarily fixed the effect size $f$ of the largest main effect at 0.4 for every model so that relative power could be better perceived. I also showed in section 7 that, under the $\mathrm{Y}=\mathrm{H} \cdot \mathrm{E}$ model the difference between strain means in a one-way design depends on the environment in which they are reared. If $\int$ strains with values for heredity $\mathrm{H}$ equally spaced by $\mathrm{h}$ units are all reared in $E_{1}=e$ then the standard deviation of strain means is

$$
\sigma_{H}=\frac{h e}{2} \sqrt{\frac{(J+1)(J-1)}{3}}
$$

which includes the e term reflecting the rearing environment. If they are instead reared in $\mathrm{K}$ different environments, as in the target article,

$$
\sigma_{\mathrm{H}}=\frac{(\mathbf{K}+1)}{2} \cdot \frac{h \mathrm{e}}{2} \sqrt{\frac{(\mathrm{J}+1)(\mathrm{J}-1)}{3}}
$$

That is, multiplicative interaction increases the main effect of strain by a factor $(K+1) / 2$. If this be seen as independence, then new spectacles are in order.

The developmentalist seeking to understand functional 
relations needs better measurement of the fundamental processes, not just better statistics. Bookstein argues persuasively for this and provides instructive examples in his own applications of tensor biometrics (Bookstein 1987) I agree that two-way ANOVA does not really provide a measure of interaction in the strict sense. Perhaps we should name the interaction mean squares an indicator. Now, can we ever measure $H, E$ and $H \times E$ interaction in their own units? For environment, many obvious examples of degrees of temperature, $\mathrm{mg} / \mathrm{kg}$ for a dietary component, hours spent reading, and so on, are familiar. Current conceptualization and attempts at measurement of environment in human behavior genetics leave much to be desired (Wachs 1983), but proper measures are possible. Heredity, especially the genetic aspect, poses greater difficulty because it is inherently categorical. For example, the "jimpy" $(j p)$ gene in mice differs from the normal allele by a substitution of an adenine for a guanine nucleotide base in the DNA (Nave ot al. 1987). The genetic variable strongly affects the abundance of myelin proteolipid protein (Gardinier \& Macklin 1988), but a measure of the protein is not a measure of the gene itself, nor is the amount or spatial distribution of myelin in the nerve bundle a measure of the gene because numerous other genetic loci and interacting physiological processes combine to govern the result (Lemke 1988).

Given that genotype must be a categorical variable, it car be represented by a dummy variable in a multiple regression equation for suitably designed experiments; and this can provide an index of $\mathbf{H} \times \mathbf{E}$ interaction. For example, Bulman-Fleming and Wahlsten (1988) found that the adult brain weights (measured in milligrams) of inbred BALB/cWah2 mice declined linearly with litter size (measured in number of pups). However, the slope of the relationship was significantly steeper when the mice were derived from ovarian tissue grafted into an inbred B ALB/c nother (5 mg smaller for each additional pup) than when grafted into an $F_{1}$ hybrid mother ( $3 \mathrm{mg} /$ pup). 15 the slope of the line in $\mathrm{mg} /$ pup a measure of the maternal environment, whereas the $2 \mathrm{mg}$ / pup difference 11 8 ope measures interaction? Neither is a measure. What we measure is brain size of mice from litters of size 2. brain size of mice from litters of size 3 , and so on. A lope of $5 \mathrm{mg} /$ pup is then an inference drawn with the aid of linear regression across litters. Because the difference in brain size between different litter sizes must represent an effect of environment, it may be seen as a pure indicator of environment alone, but the significant interaction alerts us to the fact that the value of $5 \mathrm{mg} / \mathrm{pup}$ is struin dependent; as well.

1. olosely related matter is raised by Carlier \& Marchaland, who point out that inbred strains differ in maternalenvironment as well as genotype and that consequevly a strain-by-environment interaction cannot disriminate between gene-environment interaction and rateraction with maternal environment. They are absontefy nght about this. Henderson fails to make this important distinction. I myself have emphasized the confounding of genetic (G) and $\mathrm{E}$ effects in strain studies Wohlsten 1979), and results confirming the importance of raternal environment have been reported from my

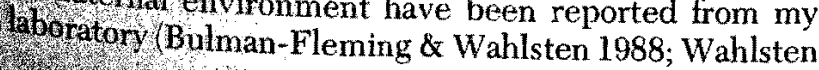

1983; Wainwright 1980). Is it fair and proper that I should now be hoist on my own petard? In the target article I was careful to talk about the heredity of a strain and to use the symbol $H$ rather than the customary $G$ found so pervasively in behavior genetics texts, but apparently I was not careful enough. There are passages, such as the second paragraph of Section 4 , where the distinction between $H$ and $G$ is obscure. In a factorial experiment comparing inbred strains, heredity is "an operationally defined entity which includes the usual direct chromosomal influence .. . plus the less-widely recognized differences in maternal environment" (Wahlsten 1983, p. 220).

The studies by Carlier and her co-workers show how the maternal environment itself can interact with genotype. Psychologists are gradually becoming aware of the importance of the very early environment for behavior (e.g., Gutzke \& Crews 1988; Smotherman \& Robertson 1988). The comments of Carlier \& Marchaland as well as Harrington pose a challenge for human adoption studies because adopted away twins always share a prenatal environment and the singleton adoptee spends at least nine months in an environment provided by its genetic mother. As if things were not already complicated enough, we must now be aware of maternal effect genes (Winslow et al. 1988) and chromosomal imprinting (Reik et al. 1987; Sapienza et al. 1987). C'est la vie!

Crow and van Noordwijk suggest that gene effects may be highly nonadditive at one level, the molecular level in particular, and yet appear additive at another level. Although these points are made in defense of heritability analysis, they warrant careful study on their own merits because of the developmental content. I cannot agree with Crow's strong statement that "tiny increments of anything are additive." This fundamental theorem of calculus cannot explain the behavior of certain deterministic but nonlinear dynamic system $\bar{s}$ of interactions under conditions far from equilibrium - the realm of so-called "chaos" (Gleick 1987; Grebogi et al. 1987). Such systems are characterized by: a sensitive dependence on initial conditions that makes long-term prediction of macroscopic behavior such as weather all but impossible from the standpoint of a collection of locally acting causes.

Hyperion, a moon of Saturn, has an orbit so chaotic that a measurement accurate to 10 digits would not be sufficient to know its location, even crudely, a mere two years later (Killian 1989); it is safe to say that it will still be orbiting Saturn, but for many asteriods the limits of their orbits are not assured. The history of physical science on the earth might read quite differently if Newton had sat beneath a lurching, irregular Hyperion among a multitude of moons rather than the spherical solitaire he knew so well. I suspect that Crow and Van Noordwijk are right about definite nonadditivity at one level and apparent additivity at another, and that chaos theory will prove applicable to embryonic and social development alike. If so, any claim that valuable information about mechanisms of development can be gleaned from patterns of correlations among measures of the outcomes of development is dubious. [See also Skarda \& Freeman: "How brains make chaos in order to make sense of the world" BBS 10(2) (1987)] 
5. Should ANOVA be banned? Although Bookstein seems to advocate a ban on ANOVA, I do not. Plomin attributes to me the view that, because of the low power of ANOVA to detect interaction, the traditional analysis of variance model should be abandoned and the messenger shot. Detterman echoes this view.

My opinion, as stated in the target article, is that (a) if a researcher wants to use two-way ANOVA to test additivity, then a large sample size should be used to insure sufficient power for the test of interaction, and (b) if the functional relationship between two factors such as $\mathrm{H}$ and $\mathrm{E}$ is nonadditive and perhaps multiplicative, then it makes no sense to ascribe a definite percentage of the total variance to mutually exclusive and independent causes. Thus, I maintain that the ANOVA is appropriate in some situations but not in others. In section 13 of the target article, I suggest that it is useful in the "early phases of investigation." While sympathizing with the view of Cheverud that the main problem is not so much with ANOVA as with developmental theory, I am sensitive to the criticism by Bullock that calling for larger sample sizes may' serve to perpetuate the "undue hegemony of ANOVA" in psychology.

Especially in a one-way research design, partitioning the variance can be very helpful. Knowledge that cognitive gender differences sometimes account for a paltry $1 \%$ of total test score variance (Hyde 1981) and that the magnitude of the difference is approaching the vanishing point (Feingold 1988) can and should inform current debate about gender discrimination in education and hiring. Estimating the strength of an effect, which implicitly requires a partition of variance, allows us to make a wise choice of sample size on the basis of power calculations. When two or more factors vary simultaneously, however, the difficulties with ANOVA multiply and the tidy division of variance loses credibility.

6. What good is heritability? While advocating a flexible approach to data analysis and ANOVA, I, along with Hirsch, see the net contribution of the concept of heritability in behavior genetics as negative. Bookstein also expresses concern that without a better understanding of functional relations path modelling "is actively misleading." Kempthorne urges that most of the literature on heritability of human behavior be ignored. Other commentators, however, offer a spirited defence of this controversial $h^{2}$.

Heritability is central to human behavior genetics as it is commonly practised, but Bullock finds it difficult to believe my representation of the field is accurate. I direct him to the comments of Crow, Detterman, Henderson and Plomin, and to the leading text by Plomin et al. (1980), for up-to-date examples. McGuffin \& Katz wonder whether any behavior geneticist really sees the estimation of $h^{2}$ as an end in itself or cares whether the value is 0.8 or 0.6 or 0.4 . Here we can examine the two most recent semi-official overviews of the field in the Annual Review of Psychology. Henderson (1982) presents numerous estimates of the heritability of $I Q$, personality, and psychopathology. He gives a tentative estimate that narrow heritability of $I Q$ might be "between .3 and .6," and he points out that more recent studies using better methodology yield lower heritability values. Loehlin et al. (1988) question Henderson's interpretation of history and, on the basis of even more recent data, assert: "It now appears that heritability estimates of general intelligence are back up again ..." (p. 103) and have "reversed the trend toward lower heritability estimates" (p. 104). Peer commentary on the Plomin and Daniels target article in $B B S[10$ (1) 1987] also reveals some who care a great deal about the precise numerical value.

It is sometimes suggested that heritability analysis is justified because a finding of $\mathrm{H} \times \mathrm{E}$ interaction is a rare occurrence. Plomin, echoed by Detterman, argues this point. Carlier \& Marchaland note the low prevalence of reports of genuine gene-environment interaction in behavior genetics. In weighing the evidence, we should keep in mind that, in the pages of a journal like Behavior Genetics, few serious attempts to test for $\mathrm{H} \times \mathrm{E}$ or $\mathrm{GxE}$ interaction are to be found at all. The most common design used by laboratory researchers in this field is a genetic crossing or selection experiment with all subjects reared in similar circumstances. We must also contend with the zeitgeist in the field so well satirized by Salsburg (1985); "having a significant interaction is a little like eating chicken with your fingers in public or wearing track shoes to a wedding. Somehow it is all your fault, and you are not quite sure what you have done wrong." He claims that "editors scream your experiment is no good" when presented with interactions. I have heard tales of this happening to my friends, and it has certainly hap. pened to me. There may be a reporting bias in the literature.

Among active behavior genetics researchers, our two most senior colleagues, Benson Ginsburg and John Paul Scott, began their studies on mouse social behavior with discrepant findings (Ginsburg \& Allee 1942; Scott 1942) produced by interaction with rearing and testing conditions (Ginsburg 1967). Ginsburg has been an interactionist even since, so we might posit a critical period for acquiring a developmental perspective. In any instructive review of research on early experience and mouse strains, Erlenmeyer-Kimling (1972) noted that "geneenvironment interactions are numerous and . . . treatment effects are frequently reversed in direction for different genotypes." (p. 201) I have not done a rigorous count, but I am impressed by the large number of my colleagues who have reported or discussed interactions recently (e.g. Crabbe et al. 1988; Donovick \& Burright 1984; Goodlett et al. 1987; Graf 1987; Satinder \& Sterling 1983; Wilson \& Sinha 1985; Zacharko et al. 1987). Others are mentioned in the target article. Detterman's claim about "the absence of persuasive data indicating that interactions are important to a behavior genetic model" is an incredible statement that is a denial of the literature, not a review of it. Those who are blind to the existence of interaction will never progress to a discussion of more challenging issues, such as the distinction between interaction and separability mentioned by Bookstein and elaborated by Gregorious and Namkoong (1987).

In future, anyone who does review the literature on $\mathrm{H}$ $\times E$ interaction would be well advised to assess not only whether the interaction $F$ ratio was significant at $\alpha=0.05$ but what the power of the test was. Examples in the target article suggest that reports of significant interaction will tend to be infrequent even when $\mathbf{H}$ and $\mathrm{E}$ are not additive. When power is low, results will also be difficult 


\section{LOCOMOTOR ACTIVITY}

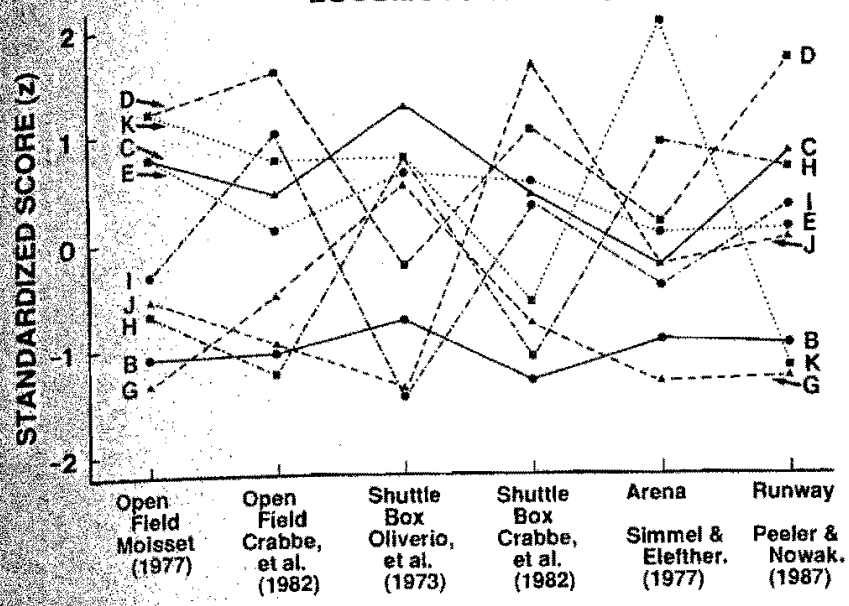

Figure 1, (Wahisten) Locomotor activity in five studies of the Bailey recombinant inbred mouse strains and their two progenitor strains. In each study, the standard deviation of the nine strain means was determined. The value of $z$ represents the number of standard deviations by which a strain mean differed from the mean of all nine strains in the study in question. The varous studies assessed locomotor activity in either an open field (Crabbe et al. 1982; Moisset 1977), a shuttle box without electric shock (Crabbe et al. 1982; Oliverio et al. 1973), an arena (Simmel \& Eleftheriou 1977) or a straight runway (Peeler \& Nowakowski 1987). Abbreviations: B, BALB/cByJ; C, C57BL 6ByJ; D, CXBD/By; E, CXBE/By; G, CXBG/By; H, CXBH/By I CXBI/By; J, CXBJ/By; K, CXBK/By.

to replicate, so Plomin's claim that failure to replicate plagues the $\mathrm{H} \times \mathrm{E}$ literature supports my thesis. Even more telling is a point he failed to mention: Main effects often do not replicate either. That is, the rank orders of strains given similar tests of behavior often differ greatly between laboratories (Wahlsten 1978). Figure l presents standardized mean values of motor activity of the seven Bailey (By) recombinant inbred strains and their two progenitors in five laboratories. The C57BL/6ByJ strain is generally high and $\mathrm{BALB} / \mathrm{cBy}$ is generally low, but the recombinants show far less consistency. Such discrepant results indicate a strong interaction of strain with either rearing or testing conditions. Peeler (1986) has shown that in the same laboratory the apparent genetic influence on activity depends on the time of day when testing is done and prior experience in the apparatus. As Hirsch points out only a small fraction of possible interactions ean be seriously assessed in our experiments, but those not serutinized in a factorial design can intrude nonetheless and make replication in different situations quite unreliable. Kline contends that low power to detect interaction does not mean it must be present every7were. None will disagree. However, low power does warn ws that failures to detect or replicate an interaction do not prove that the factors are additive.

t targe number of informative interactions has been roported With impressive consistency in the field of teratology as well as in studies of mouse genes such as Niable vellow" (Frigeri et al. 1988), "obese" (Bellward and Dauncey 1988) and "staggerer" (Guastavino 1988), not 6 mention strains of wheat (Roberts \& Larson 1985) 9nd Mendel's favorite, the garden pea (Reid \& Murfet
1977). Numerous studies of developmental genetics support Bullock's argument that $\mathrm{H} \times \mathrm{E}$ interactions are likely to occur in nature. Goodall also says we should expect to find some interaction.

Given this, we could insist that the statistical hypothesis of nonadditivity be treated as the null hypothesis and that additivity be seriously entertained only when the null hypothesis can be firmly rejected. This would not require any revolution in mathematics. Simply do a transformation of the data before every ANOVA and ask whether the interaction is significant. If $\mathrm{H}$ and $\mathrm{E}$ really are additive, this should create an interaction that could be removed by a suitable reverse transformation. On the other hand, if power were very low, the transformation would be of little consequence either way. Goodall proposes that transformation be regarded as an integral part of data analysis and that alternative models with and without transformation be routinely considered in studies of heredity and environment. This could strengthen many studies. My opposition to ad hoc transformations applies to studies where only one analysis of a transformed measure is presented to the reader as the only reasonable interpretation of the data.

Detterman, Henderson, and Plomin assert strongly that no $\mathrm{H} \times \mathrm{E}$ interaction has been demonstrated with humans. The immense literature on well-established Mendelian disorders refutes them decisively. For phenylketonuria and similar metabolic disorders, the child with two recessive genes is less able to regulate the levels of important substances in the blood and is more sensitive to variations in the diet. Whether the genetic defect would also interact with psychological treatments, as suggested by Henderson, is difficult to know because ethics forbid that a healthy child should be deliberately subjected to a poor education in the name of science. In the ethereal realm of "polygenic" behaviorswhere genes cannot be identified or counted, no conclusive test of specific GxE interaction exists. Nevertheless, in the study of psychopathology, it is often claimed that genotype determines susceptibility or vulnerability to the induction of psychosis by adverse experience (Kendler \& Eaves 1986; Schulsinger et al. 1987; Tienari et al, 1987). If all is additive, why do psychiatrists bother with this blatantly interactionist theory?

When the possibility of $\mathrm{H} \times \mathrm{E}$ interaction is acknowledged, Detterman and Plomin insist that $\mathrm{h}^{2}$ is still good because the interaction accounts for relatively little variance. Crow proves $\mathrm{h}^{2}$ expected with additivity is only slightly less when a multiplicative model is used, and with several types of transformation. Cheverud's position that interaction does not greatly bias the value of $h^{2}$ appears confirmed here, although there are other situations where the bias can be larger (Lathrope et al. 1984). Better support for the central thesis of the target article can hardly be imagined. Crow proves that the $h^{2}$ coefficient derived from parent-offspring regression is insensitive to the underlying structure of the data. Hence, $\mathbf{h}^{2}$ cannot help us discover that structure or gain deeper insights into the nature of development. Looking at his model from the standpoint of an interactionist, let us inquire about the effects of changing the environment by the same amount for every child in the population. The additive model says that every child's phenotype should increase by the same amount. For the multiplicative 
model, we need some numbers. Suppose both $\mathrm{H}$ and $\mathrm{E}$ factors have means of 3.0 and standard deviations of $1.0 \mathrm{in}$ the population, and that $\mathrm{H}$ and $\mathrm{E}$ are uncorrelated. Now add 2.0 to each child's $\mathrm{E}$ value. For a child with a low $\mathrm{H}=$ 1.0 , the phenotype will increase by only 2 units, whereas a lucky one with $\mathrm{H}=5.0$ will increase by 10 units, fully five times the increase for the less fortunate peer. Being oblivious to the functional relation between $\mathbf{H}$ and $\mathbf{E}$, heritability analysis cannot predict the effect of changing the environment.

However Crow, Goodnight, and Kempthorne assure us that $\mathbf{h}^{2}$ is useful in predicting the response to selective breeding, even when $\mathrm{H}$ and $\mathrm{E}$ are not at all additive. Sometimes the prediction is quite good, yet there are instances, especially with reproductive traits, when response to selection falls short of expectations from the $\mathrm{h}^{2}$ value (Nordskog 1977). 'Wright's (1978) assessment of several decades of work on animal breeding also warrants caution. One particular shortcoming of the straightforward heritability approach is that it may hold for the first few generations of selection, but it cannot predict when or where the selection limit will be reached or whether there will be asymmetry of response in high and low lines. Strictly speaking, $h^{2}$ from parent-offspring regression really does not predict anything. Suppose we estimate $h^{2}$ by computing the regression of the mean score of the parents on the mean score of their offspring. Hill (1970) has demonstrated that the most efficient way to estimate $\mathrm{h}^{2}$ is in fact to do a selection experiment for only one generation. Selection is essentially a parent-offspring regression study where the middle-scoring parents are not included. Perhaps one generation of selection can predict the response to selection in the next generation. This tells us simply that the properties of the population do not change much in one generation, whatever the true developmental relationship between $\mathrm{H}$ and $\mathrm{E}$.

Cheverud and Lipp argue that calculation of $h^{2}$ can be a useful starting point because it provides evidence of genetic variation, whereas McGuffin and Katz recommend its use as a diagnostic aid in seeking forms of a heterogeneous disorder that may be heritable. Two objections come to mind. First, in studies of selective breeding or inbred strains, genuine chromosomal genetic effects cannot be distinguished from maternal environment effects (Carrier \& Marchaland) or cytoplasmic inheritance. Likewise, twin studies are contaminated by covariance, cytoplasmic and uterine environment effects, and adoption studies are afflicted with covariance and stubborn maternal environment effects. Because $h^{2}$ is supposed to reflect only Mendelian gene effects in the numerator (Falconer 1981), it should not be reported unless other hereditary factors can be positively excluded. Second, evidence of putative genetic variation requiring further study can be shown with general purpose statistics. The approximate extent of hereditary variation among inbred strains or selected lines can be neatly summarized by estimated $\omega^{2}$ (Hays 1988). If MZ twins show a much higher intra-class correlation than $\mathrm{DZ}$ twins or if parent-offspring regression is substantial, the presence of hereditary variation is a reasonable bet. Precisely what kind of hereditary mechanism are involved generally cannot be known solely from a strain or twin study. These kinds of experiments ought to be regarded as preludes to a more comprehensive study.
Unfortunately, the $\mathrm{h}^{2}$ coefficient is bound up with a very specific genetic theory, and citing a number for $\mathrm{h}^{2}$ implies to many readers in psychology that they have just beheld the finale. What $\mathrm{h}^{2}$ means to Falconer (1981) or Plomin et al. (1989) is automatically conveyed to a psychology student familiar with these authorities, even though the writer himself does not take the precise value of $h^{2}$ too seriously. What $\mathrm{h}^{2}$ means to those with less education, I shudder to think.

Crow regards $h^{2}$ analysis as a useful, albeit indirect, approach to assessing the impact of environmental variation, $\mathrm{e}^{2}$. In this vein, Heath et al. (1985) use $\mathrm{h}^{2}$ values to draw conclusions about changes in schooling in Norway, and Plomin and Daniels (1987) cite results of path analysis to support their proposal that personality is unaffected by experiences common to members of a family. I cannot see how global statements about environmental variance tell us anything more about the specific actions of experience than the global $h^{2}$ tells us about the number, location, and physiological characteristics of relevant genes. As Wachs (1983) and Bookstein aver, to learn how environment affects the development of behavior we must have accurate measures of relevant features of experience. Furthermore, heredity and environment are not the only sources of individual differences in a population. Durable and noteworthy variations in the structure of an organism can emerge via processes internal to the embryo that are neither hereditary nor responses to local variations in the environment. (Kurnit et al. 1987; Lewontin 1982; Wahlsten $1987 \mathrm{~b} ; 1989 \mathrm{~b})$. With three sources of individual differences the potency of one cannot be specified by studying another.

Goodnight suggests that the absolute value of $h^{2}$ is not particularly useful but that the relative magnitudes of additive genetic and dominance variance have some relevance. Crow and van Noordwijk see a role for $h^{2}$ in evolutionary theory, and Crow thinks evolution must proceed gradually, in small, additive increments. On the other hand, several theorists see a close link between development and evolution, and, from this perspective, question the neoDarwinian dogma (Ho \& Fox 1988). As suggested by van Noordwijk, phenotypic plasticity can play a very important role in molding an organism to its niche (Cavalli-Sforza 1974; Greene 1989); hence, geneenvironment interaction should be central to evolutionary theory (e.g., Via \& Lande 1985).

Finally, McGuffin and Katz suggest that my discussion of a link between heritability and eugenics sets up a straw man, and they claim no reputable human behavior geneticist would use heritability for eugenic purposes. It seems to me that the link between $\mathrm{h}^{2}$ and selective breeding is inherent in a quantitative genetic model and has little to do with reputation. Because of this link, the heritability coefficient is not ethically neutral when it is computed for human IQ. Even if the scientists doing the computation are not proponents of eugenics, others may and probably will vulgarize their writings for eugenic purposes (Stein 1988). Within recent memory, some quite reputable geneticists have promoted selective sterilization of people with low intelligence (see Hirsch 1981; Nanney 1986). Today the Pioneer Fund seeks to advance its program of "racial betterment" (Lichtenstein 1977; May 1960) through large grants to several members of the Behavior Genetics Association (McCann \& Currie 1989). 
The stuff of controversy should not be brushed aside as mere straw.

7. Charges of bias. The target article, Plomin says, implies that behavioral geneticists, including himself have not considered GxE" and have been "ignoring $\mathrm{GxE}$. However, the target article in section 4 credits none other than Plomin et al. (1977) with proposing a formal $2 \times 2$ test of interaction. It cites five other items with him as senior author. My article states that in behavior genetics "the problem is not a lack of understanding about the importance of interaction in theory. Rather there is a divergence of opinion about its occurrence in reality." The commentaries prove the latter point. As I also stated in the target article, the problem of low power is "generally understood by expert statisticians. A paper by Eaves et al. (1977) is cited as an example. Henderson quotes a sentence written by John fuller in response to my 1979 paper to show how behavior geneticists supposedly knew all about interaction 10 years ago. However, my 1979 paper did not raise the issue of power of ANOVA to detect interaction. Furthermore, it is timely now to repeat Fuller's next sentence in that response concerning interactions: "It is good to be reminded that overlooking their existence may lead to faulty conclusions and premature generalization" (Fuller 1979).

Plomin states that I set out to denigrate heritability. It may appear that way to some people, so let me emphasize that the points made about the low power to detect $\mathrm{H} \times \mathrm{E}$ interaction apply to any kind of two-way or higher order interaction. Hirsch is right that assigning a percentage to environmental variance confronts the same problems as heritability. As van Noordwijk instructs, the same issues apply if we want to partition environmental sources of variance. Goodall stresses that ANOVA is perfectly general in this respect. Dudley presents three cells of an ideal adoption design with four groups. The fourth cell, children born into favorable homes but adopted into relatively poor tiomes, has now been filled in an excellent study done by France (Capron \& Duyme 1989). The increase in IQ provided by going from a poor background to a favorable family environment was comparable to the decrease resulting from transfer in the opposite direction. The two-way interaction was not significant, but it suffered from the very problem of low power discussed in the target article.

8. Two kinds of gravity. The parody of Newton's law Attracted some attention. Lipp was struck by the meaning that evidently missed Detterman. We should thank Detterman for his lovely graphs, because they bolster the conclusions Idrew from Figure 2(a) in the target article. Henderson and Detterman want to see results when nieh wider ranges of mass and distance are used, so I provided the intrepid experimenter in section 6 of the target article with several burly assistants and sent them ontside to a football field to gather data. Unfortunately, vind increased the error variance, and nothing was signifTant at all Kline says we only need to know the mass of becevevant planet in order to calculate a person's weight Cive body size is constant throughout the universe. Given. I live in Edmonton, Alberta, on the planet earth. Cark kine therefore tell me my weight? van Noordwijk says a choice between models is determined by practical purposes and becomes most important when we want to extrapolate. Newton's law speaks to this matter, too. It could not be decisively verified by reference to the facts used to formulate the law, no matter how closely data and theory matched. It had to predict something new. This took place in 1846 when Leverrier used Newton's law to predict the location of an unknown planet from perturbations in the orbit of Uranus and then the existence of Neptune was confirmed by Galle and d'Arrest at the Berlin observatory using Leverrier's coordinates (Grosser 1979). What could be less practical than the exuberant delight of star gazers at this brilliant feat? It didn't really make much practical difference until the era of rocket journeys over 100 years later. Fortunately for us, the likes of Newton, Edmund Halley, and their followers would settle for nothing less than truth. On this day, August 25, 1989, the Voyager II space satellite flew past Neptune, guided by knowledge of a law of nature that predicted because it explained.

\section{ACKNOWLEDGMENT}

Skillful typing of this manuscript was done by Jan Zielinski.

\section{References}

Letters " $a$ " and " $r$ " appearing before authors" initials refer to target article and response respectively.

Adams, A. \& Bullock, D. (1986) Apprenticeship in word use: Social convergence processes in learning categorically related nouns. In: The development of word meaning, ed. S. A. Kuczaj \& M. D. Barrett. Springer-Verlag. [DB]

Adams, K. M., Brown, G. G. \& Grant, 1. (1985) Analysis of covariance as a remedy for demographic mismatch of research subject groups: Some sobering simulations. Joumal of Clinical and Experimental Neuropsychology 7:445-62. [DVC]

Alberch, P. (1983) Mapping genes to phenotypes, or the rules that generate form. Evolution 37:861-63. [DAC]

American Psychiatric Association (1980) Diagnostic and statistical manual of mental disorders, 3d ed. American Psychiatric Association. [PM]

Anastast, A. (1958) Heredity, environment, and the question "How?" Psychological Review 65:197-208. [JH]

Areen, J. (1985) Case material on family law. Foundation Press. [PHS]

Atkinson, B. G. Walden, D. B., eds. (1985) Changes in eukaryotic gene expression in response to environmental stresis. Academic Press. [aDW]

Baker, B. O, Hardyck, C, D. \& Petrinovich, L. F. (1966) Weak measurements $v_{s}$, strong statistics: An empirical critique of $S . S$. Stevens's proscriptions on statistics. Educational and Psychological Measurements 26:291-309. [DAC]

Bates, D. M: \& Watts, D. G. (1988) Nonlinear regression analysis and its applications. Wiley, [CG]

Bateson, P. (1987) Biological approaches to the study of bohavioral development. International Joumal of Behavioral Development 10:I22. [aDW, PM]

Bateson, P. \& D'Udine, B. (1986) Exploration in two inbred strains of mice and their hybrids: Additive and interactive models of gene expression. Animal Behaviour 34:1026-32. [rDW]

Baner, S. J. \& Sokolowski, M. B. (1985) A genetic analysis of path length and pupation height in a natural population of Drosophila melanogaster. Canadian Journal of Genetics and Cytology 27:334-40. [rDW]

Beardsley, T. (1988) Developmental dialectics. Scientific American 259(Nov.):40-41. [rDW]

Bebbington, P. E. Brugha, T., MacCarthy, B., Potter, J., Sturt, E., Wykes, T. Katz, R. \& McGuffin, P. (1988) The Camberwell collaborative depression study. 1. Depressed probands: Adversity and the form of depression. British Joumal of Psychiatry 152:754-65. [PM]

Bebbington, B. E., Hurry, J., Tennant, $\mathrm{C}_{*}$, Sturat, E. \& Wing, J. K. (198I) Epidemiology of mental disorders in Camberwell. Psychological Medicine $11: 561-79 . \quad[\mathrm{PM}]$

Bellward, K. \& Dauncey, M.J. (1988) Behavioural energy regulation in lean 
and genetically obese (ob/ob) mice. Physiology and Behavior 42:43338. $[\mathrm{rDW}]$

Benkel, B. F. \& Hickey, D. A. (1987) A Drosophila gene is subject to glucose repression. Proceedings of the National Academy of Sciences USA 84:1337-39. [aDW]

Berger, J. O. \& Berry, D. A. (1988) Statistical analysis and the illusion of objectivity. American Saientist 76:159-65. [rDW]

Bignami, G. \& Bovet, D. (1965) Experience de sélection par rapport à une réaction conditionnée d'évitement chez le rat. Comptes Rendus de l'Académie de Science 260:1239-44. [H-PL]

Billings-Gagliardi, S. \& Wolf, M. K. (1988) Shiverer*jimpy double mutant mice. IV. Five combinations of allelic mutations produce three morphological phenotypes. Brain Research 455:271-82. [rDW]

Blau, H. M., Pavlath, G. X., Hardeman, E. C., Chiu, C.P., Silberstein, L., Webster, S. G., Miller, S. C. \& Webster, C. (1985) Plasticity of the differential state. Science 230:758-66. [aDW]

Bolles, R. C. (1988) Why you should avoid statistics. Biological Psychiatry 23:79-85. [aDW]

Boneau, C. A. (1960) The effect of violations of assumptions underlying the $T$ test. Psychological Bulletin 57:49-64, [DAC]

Bookstein, F. L. (1987) Describing a craniofacial anomaly: Finite elements and the biometrics of landmark locations. American Journal of Physical Anthropology 74:495-509. [rDW]

Bouchard, T. J. \& McGue, M. (1981) Familial studies of intelligence: A review. Science 212:1055-58. Tabulation sheets and lists of "Papers included" and "Papers excluded" (unpublislied). [RMD]

Bovet, D., Bovet-Nitti, F. \& Oliverio, A. (1969) Cenetic aspects of memory and learning in mice. Science 163:139-49. [H-PL]

Bowers, K. E. (1973) Situationism in psychology: A critique, Psychological Review 80:307-36. [aDW]

Box, G. E. P. (1953) Non-normality and tests on variance. Biometrika 40:31835. [[DAC]

(1954) Some theorems on quadratic forms applied in the study of analysis of variance problems. I. Effect of inequality of variance in the one-way classificatign. Annals of Mathematical Statistics 25:290-302. [DAC]

Box, G. E. P. \& Cox, D. R. (1964) An analysis of transformations. Journal of the Royal Statistical Society. Series B 26:211-43. [aDW]

Box, G. E. P., Hunter, W. G. \& Hunter, J. S. (1978) Statistics for Experimenters. John Wiley, [CO]

Broadhurst, P. L., Fulker, D. W. \& Wiloock, J. (1974) Behavioral genetics. Annual Review of Psychology 25:389-415. [JH]

Brockington, I. F., Kendell, R. E. \& Leff, J. P. (1978) Definitions of schizophrenia: Concordance and prediction of outcome. Psychological Medicine 8:387-98. [PM]

Brush, F. R., Baron, S., Froehlich, J. C., Ison, J. R., Pellegrino, L. J., Phillips, Sakellaris, P. C. \& Williams, V. N. (1985) Genetic differences in avoidance learning by Rattus norvegicus: Escape/avoldance responding, sensitivity to electric shock, discrimination learning, and open-field behavior. Journal of Comparative Psychology 99:60) -73. [rDW]

Bullock, $\mathrm{D},(1987)$ Socializing the theory of intellectual development. In: Meaning and the grouth of understanding; ed. M. Chapman \& $\mathrm{K}$. A. Dixon. Springer-Verlag, [DB]

Bulman-Fleming, B, \& Wahlsten, D. (1988) Effects of a hybrid maternal environment on brain growth and corpus collosum defects of inbred BALB/c mice: A study using ovarian grafting. Experimental Netrology 99:636-46. [rDW]

Byerley, W., Mellon, C., O'Connell, P., Laloul, J-M., Nakamura, Y., Leppert, M. \& White, R. (1989) Mapping genes for manic-depression and schizophrenia with DNA markers. TINS 12:46-48. [H-PL]

Capron, C. \& Duyme, M. (1989). Assessment of effects of socio-economic status on IQ in a full cross-fostering study. Nature 340:552-54. [rDW]

Carlier, M. \& Nosten, M. (1987) Interaction between genotype and pre- or postnatal maternal environments: Examples from behaviors observed in inbred strains of mice. In: Functional teratogenesis functional effects on the offspring after parental drug exposure, ed. T. Fujii \& P. M. Adams. Teikyo University Press. [aDW, MC]

Carlier, M., Nosten-Bertrand, M. \& Michard-Vahnee, G. (in press) The separation of genetic from maternal effects. In: Techniques for the genetic analysis of brain and behavior: Focts on the mouse, ed. D. Goldowitz, D. Wahlsten \& R. Wimer. Elsevier. [MC]

Carlier, M. \& Roubertoux, P. L. (1986) Le développement des comportements: Effet des interactions entre le génotype et l'environment matemel. Confrontations Psychiatriques 27:63-88. [MC]

Carlier, M., Roubertoux, P. L. \& Cohen-Salmon, C. (1983) Early development in mice I. Genotype and postuatal maternal effects. Physiology and Behavior 30:837-44. [MC]

Carroll, R. J. \& Ruppert, D. (1988) Transformation and weighting in regression. Chapman \& Hall. [CG]
Carroll, S. B., Winslow, G. M., Schupbach, T. \& Scott, M. P. (1986) Maternal control of Drosophila segmentation gene expression. Nature $323: 278-80$, [aDW]

Carter, C. O. (1977) Letter, Noture 266:279. [RMD]

Castro, C. A. \& Rudy, J. W. (1989) Early-life malnutrition impairs the performance of both young and adult rats on visual discrimination learning tasks. Developmental Psychobiology 22:15-28. [DAC]

Cavalli-Sforza, L. L. (1974) The role of plasticity in biological and cultural evolution. Annals of the New York Acculemy of Sciences 231:4359. [rDW]

Cavalli-Sforza, L. L. \& Feldman, M. W. (1973) Cultural versus biological inheritance: Phenotypic transmission from parents to children (A theory of the effect of parental phenotypes on children's phenotypes). American Journal of Human Genetics 25:618-37. [aDW]

Chauvin, R. (1977) Ethology: The biological study of animal behatior. translation. Intemational Universities Press. [DAC]

Cheverud, J. (1984) Quantitative genetics and developmental constraints on evolution by selection. Journal of Theoretical Biology 110:15572. $[\mathrm{JMC}]$

Cheverud, J. (1988). The evolution of genetic correlation and developmental constraints. In: Population genetics and evolution, ed. G. de Jong. Springer-Verlag, [JMC]

Cohen, J. ( 1962) The statistical power of abnormal-social psychological research: A review. Journal of Abnomal and Social Psychology 65:145 53. [SEM]

(1977) Statistical power analysis for the behavioral sciences, revised editiou. Academic Press. [aDW, SEM]

(1978) Statistical power analysis for the behavioral sciences, $2 \mathrm{~d}$ ed Erlbaum. [rDW]

Cohen, J \& Coheu, P. (1975) Applied multiple regression/correlation analysis for the behavioral sciences. Wiley. [RMD]

1983) A pplied multiple regression: Correlation analysis for the behavioral sciences, 2d. ed. Erlbaum. [RP]

Cole, W. A. \& Trasler, D. G. (1980) Gene-teratogen interaction in insulininduced mouse exencephaly. Teratology 22:125-39. [aDW]

Colernan, D. L. (1981) Inherited obesity-diabetes syndromes in the mouse In: Mammalian Genetics and Cancer, ed. E. S. Russell \& E. Schull, Alan R. Liss. [rDW]

Collins, B L. (1979) Selective breeding for the degree of functional lateralization in mice. Behavior Genetics 9:443-44. [H-PL]

Cooper, R. M. \& Zubek, J. P. (1958) Effects of enriched and restricted early environments on the learning ability of bright and dull rats. Conadian Journal of Psychology 12:159-64. [aDW]

Crabbe, J. C., Deutsch, C. M., Tam, B. R. \& Young, E. R. (1988) Environmental variables differentially affect ethanol-stimulated activity in selectively bred mouse lines. Psychopharmacology 95:103-08. [rDW]

Crabbe, J. C., Rigter, H. \& Kerbusch, S. (1982) Analysis of behavioural responses to an $\mathrm{ACTH}$ analog in $\mathrm{CXB} / \mathrm{By}$ recombinant inbred mice. Behavioural Brain Research 4:289-314. [rDW]

Cronbach, L. J. K Snow, R. E. (1975) Aptitudes and instructional methods: A handhook for research on interactions. Irvington. [DKD]

(1977) Aptitudes and instructional methods: A handbook for research on interactions. Irvington, [SEM]

Crouse, J \& Trusheim, D. (1988) The case against the SAT. University of Chicago Press. [PHS]

Crusio, W. E. (in press) Quantitative genetics. In: Techniques for the genetic analysis of brain and behavior: Focus on the mouse, ed. D. Goldowitz, D. Wahlsten \& R. E. Wimer, Elsevier. [aDW, WEC]

Crusio, W. E., Schwegler, H. \& van Abeelen, J. H. F. (1989) Behavioural responses to novelty and structural variation of the hippocampus in mice. 1I. Multivariate genetic analysis. Behavioural Brain Research 32:8188. [WEC]

Darlington, R. B. (1968) Multiple regression in psychological research and practice. Psychological Bulletin 69:161-82. [RMD]

Davidson, E. H. (1987) Understanding enbryonic development: A contemporary view. American Zoologist 27:581-91. [aDW]

Davison, M. L. \& Sharma, A. R. (1988) Parametric statistics and levels of measurement. Psychological Bulletin 104:137-44.[aDW]

Debray, Q., Caillard, V. \& Stewart. J. (1979) Schizophrenia: A study of genetic models. Muman Heredity 29:27-36. [aDW]

DeFries, J. C. (1979) Comment. Theoretical adwances in behavior genetics, ed. J, R. Royce \& L. P. Mos. Sijthoff \& Noordhoff. [RP]

DeFries, J. C. \& Plomin, R. (1978) Behavioral genetics. Annual Heview of Psychology 29:473-515. [JH]

Defries, J. C., Wilson, J. R. \& McClearn, G. E. (1970) Open-field behavior in mice: Selection response and situational generality, Behatior Genetics 1(3):195-211. [H-PL]

Denenberg, V. H. (1977) Interactional effects in early experience research. In: 
Getetics, entironnent and intelligence, ed. A. Oliverio. Elsevier/North Golland Biomedical Press. [aDW]

The future of intelligence research. Intelligence 13(3) $199-204 \quad[\mathrm{DKD}]$

Dodson 5 (1989) Predator-induced reaction norms. BioScience 39:447 32. [ANN]

Nialdson. T. S. (1968) Robustness of the F-test to errors of both kind and the correlation between the numerator and denominator of the Thratio. Journal of the American Statistical Association 63:660-76. $[\mathrm{DAC}]$

onovick . . J. \& Burright, R. G. (1984) Roots to the future: Geneenvironiment coaction and individual vulnerability to neural insult. In Early brain damage, vol. 2, Neurobiology and behaviar, ed. S. Finger \& C. A. Almli. Academic Press. [rDW]

Dinn O. I \& Clark, V. A. (1974) Applied Statistics: Analysis of variance and regression. Wiley. [aDW]

Faster S S. Jr., Purves, D., Rakic, P. \& Spitzer, N. C. (1985) The changing * viet of neural specifieity. Science 230:507-11. [aDW]

Eaves, L. J. Last, K., Martin, N. G. \& Jinks, J. L. (1977) A progressive approach to non additivity and genotype-envirommental covariance in the analysis of human differences. British Joumal of Mathematical and Statistical Psychology 30:1-42. [aDW]

Edwards A. L (1979) Multiple regression and the analysis of variance. Freeman. [aDW]

1985) Experimental design in psychological research. Harper \& Row $[\mathrm{DAC}$

Einerson, I D. \& Hoaglin, D. C. (1983) Analysis of two-way tables by nedians In: Understanding robust and exploratory data analysis. Wiley. $[\mathrm{CG}]$

Einerson, I D \& Stoto, M. A. (1983) Transforming data, In: Understanding Thobust and exploratory data analysis. Wiley. [CG]

Fifenmeyer-Kimling, L. (1972) Genotype-environment interactions and the varability of behavior, In: Genetics, environment, and behavior, ed. L Ehrman G. S. Omenn \& E. Caspari. Academic Press. [arDW]

Eysenck, H. (1973) The measurement of intelligence. Williams and Wikins. [PHS]

Ewens, W/ (1979) Mathematical population genetics. Springer. [RMD

Ezekial, M \& Fox, K. A. (1959) Methods of correlation and regression andysis, 3d ed. Wiley. [GMH]

Falooner, D. (1981) Introduction to quantitatioe genetics. Longman Tress. IMMC, $\mathrm{CJG}, \mathrm{rDW}]$

Fancher, $\mathrm{R}, \mathrm{E},(1985)$ The intelligence men: Makers of the $1 Q$ controversy. Norton [aDW]

Farber. 8. L. (1981) Identical twins reared apart. Basic Books. [RMD

Farmer, A E., McGufinn, P. \& Gottesman, 1. 1. (1987) Scrutinising the validity of the definition. Archioes of General Psychiatry 44:6344. $(\mathrm{PM})$

Feingold 1 (1988) Cognitive gender differences are disappearing American Psychologist 43:95-103. [rDW]

Finlay, B. M. Wikler, K. C. \& Sengelaub, D. R. (1987) Regressive events in brain development and scenarios for vertebrate brain evolution. Brain, Behovio and Evoltation 30:102-17. [H-PL]

Fisher. $\mathrm{R}$ (1918) The correlation between relatives on the supposition of Mendelian inheritance. Transactions of the Royal society of Edinburgh 52.3904433 . IMMC]

Tisher A $\mathrm{A}$ (1930) The genetical theory of natural selection. Clarendon Aress. [FC]

1951) Linits to intensive production in animals. British Agricaltural Bulletin $4217-18,[\mathrm{JH}]$

(1058) The genetical theory of natural selection, $2 d$ ed. Dover. [C]G]

Hisher f A. \& Mackenzie, W. A. (1923) Studies in crop variation. II. The -natimal responses of different potato varieties. Journal of Agricultural Scrence 13311-20. [aDW, RMD, OK]

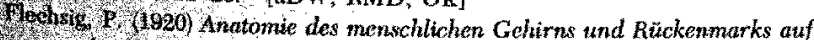
14 myplogenetisoter Grundage, Bd. 1, I Teil. Georg Thiem. [H-PL]

17nt 1 . 11 1987) Massive IQ gains in 14 nations: What IQ tests really Theasure Psychological Bulletin 101: 343-62. [PHS]

91. 1984) Linear statistical models and related methods, with applications 10 osondil, research. Wiley, $[\mathrm{CC}]$

reman. (C. M. (1973) Statistical methods for the analysis of genotypetonvironment interactions. Heredity 31:339-54. [aDW, RMD]

reach 1. W (1051) The description of aptitude and achievement tests in terms of totated factors. Psychometric monographs, No. 5 . University of Chican oress. [PIS]

1.7. 1. W. Wolt $\mathrm{G}$,

collow Woll, G. L. \& Teguh, C. (1988) Differential responses of

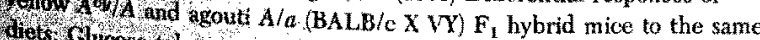
7. Tumose tolerance, weight gain, and adipocyte cellularity. interpotional lounul of Obesity 12:305-20. [rDW]
Fulker, D, W. (1970) Maternal buffering of rodent genotype responses to stress: A complex genotype-environment interaction. Behavior Genetics 1:119-124. [GMH]

Fuller, J. L. (1960) Behavior genetics. Annual Review of Psychology 11:4170. $\{\mathrm{JH}]$

(1979) Comment. In: Theoretical advances in behavior genetics, ed. J. R. Royce \& L. P. Mos. Sijthoff \& Noordhoff, [NDH]

Fuller, J. L. Thompson, W. R. (1978) Foundations of behavior genetics. Mosby. [aDW]

Futuyma, D. J. (1986) Evolutionary biology. Sinaner Associates, Inc. [DAC]

Gaito, J. (1980) Measurement scales and statistics: Resurgence of an old misconception. Psychological Bulletin 87:564-67. [aDW]

Gardinier, M. V. \& Macklin, W. B. (1988) Myelin proteolipid protein gene expression in jimpy and jimpyrsa mice. Journal of Neurochemistry 51:360-69. [rDW]

Garner, D. M. Garfinkel, P. E. (1979). The eating attitude test: An index of the symptoms of anorexia nervosa. Psychological Medicine 9:27380. [PM]

Gerhart, J. C. (1982) The cellular basis of morphogenetic change. Group report. In: Evolution and development, ed. J. T. Bonner. Springerverlag. [aDW]

Geweke, J. F. \& Singleton, K. I. (1980) Interpreting the likelihood ratio test in factor models when sample size is small. Journal of the American Statistical Association 75:133-37. [PHS]

Ginsburg, B. E. (1967) Genetie parameters in behavioral research. In: Behavior-genetic analysis, ed. J. Hirsch. MoGraw-Hill. [rDW]

Ginsburg, B. \& Allee, W. C. (1942) Some effects of conditioning on social dominance and subordination in inbred strains of mice. Physiological Zoology 15:485-506. [rDW]

Glashow, S. (1988) Tangled in superstring: Some thoughts on the predicament physics is in. The Sciences May/]une:22-25. [HN]

Gleick, J. (1987) Chaos. Viking Press. [rDW]

Goldberger, A. S. (1973) Structural equation models: An overview. In Structural equation models in the social sciences, ed. A. S. Goldberger \& O. D. Duncan. Seminar Press. [GMH]

(1978) The nonresolution of IQ inheritance by path analysis. American Joumal of Human Genetics 39:442-45. [rDW]

Collin, E. S. (1965) A developmental approach to leaming and cognition. In; Adoances in child development and behavior, vol. 2, ed. L, P. Lipsitt \& C. C. Spiker. Academic Press. [DAC]

(1985) Ontogeny, phylogeny, and causality. In: The comparative development of adaptive skills: Evohutionary implications, ed. E. S. Gollin. Erbanm. [DAC]

Goodall, G. \& Guastavino, J.-M. (1986) The neurological mutent: Scope and limitations as a tool for the genetic analysis of behaviour. In: Genetic approaches to behaviour, ed. J. Medioni \& G. Vaysse. 1.E.C. [aDW]

Goodlett, C. R., Gilliam, D. M. \& West, J. R. (1987) Differential susceptibility of long-sleep (LS) and short-sleep (SS) mice to brain weight reduction following prenatal alcohol exposure. Poster presented at the Behavior Genetics Association annual meeting. Minneapolis, June 25. [rDW]

Gottesman, I. I Shields, J. (1982) Schizophrenia: The epigenetic puzale Cambridge University Press. [PM]

Gould, S. J. (1981) The mismeasure of man. Norton. [CG]

Graf, S. A. (1987) The rover/sitter Drosophila foraging polymorphism as a function of larval development and food availability. Paper presented at the Behavior Genetics Association annual meeting. Minneapolis, June. 25. [rDW]

Grebogi, C., Ott, E. \& Yorke, J. A. (1987) Chaos, strange attractors, and fractal hasin boundaries in nonlinear, dynamies. Science 238.632 38. $[\mathrm{rDW}]$

Greene, E. (1989) A diet-indiced developmental polymorphism in a caterpillar. Science 243:643-46. [rDW]

Gregorious, H.-R. \& Namkoong, G. (1987) Hesolving the dilenmas of interaction, separability, and additivity. Mathematical Biosciences 85:5169. $[\mathrm{rDW}$

Grosser, M. (1979) The discovery of Noptune. Dover. [rDW]

Gupta, A. P. \& Lewontin, R. C. (1982) A study of reaction norms in natural populations of Drosophila pseudo obscure. Evolution 36:\$34-38. [DAC]

Guastavino, J, -M. (1988) Ethogenèse de la souris tnutante staggerer, facteurs epigenetiques et recuperations fonctionelles. These de doctorat d'État des Sciences, presenteé a L'Université Paris-Nord. [rDW]

Guttman, L. (1986) The irrelevance of factor analysis for the study of group differences. Submitted to Behavioral and Brain Sciences. [PHS]

Gutzke, W. H. N. \& Crews, D. (1988) Embryonic temperature determines adult sexuality in a reptile. Nature 332:832-34. [rDW]

Haavelmo, T. (1943) The statistical implications of a system of simultaneous equations. Econometrica 11:1-12, [GMH] 
(1944) The probability approach in econometrics, Econometrica 12 , supplement. [GMH]

Haldane, J. B. S. (1946) The interaction of nature and nurture. Annals of Eugenics 13:197-205. [JH]

Harnad, S. (1989) Publication bias: What is its magnitude and nature? Talk delivered at the First International Congress on Peer Review in Biomedical Publication. Chicago, May 10/12, 1989. [PHS]

Harrington, G. M. (1988) Two forms of minority-group test bias as psychometric artifacts with an animal model (Rattus norvegicus). Joutnal of Comparative Psychology $102 ; 400-7$. [JH]

Hays, W. L. (1988) Statistics. 4th ed. Holt, Rinehart \& Winston. [aDW]

Heath, A. C., Berg, K., Eaves, L. J., Solaas, M. H., Corey, L. A., Sundet, J., Magnus, P. \& Nance, W. E. (1985) Educational policy and the heritability of educational attainment. Nature 314:734-36. [aDW]

Hegmann, J. P. \& Possidente, B. (1981) Estimating genetic correlations from inbred strains. Behavior Genetics 11:103-114. [aDW]

Heikkila, J. J., Browder, L. W, Gedamu, L., Nickells, H. W. \& Schultz, G. A. (1986) Heat-shock gene expression in animal embryonic systems. Canadian Jaurnal of Cenetics and Cytology 28:1093-1105. [aDW]

Henderson, N. D. (1967) Prior treatment effects on open field behaviour of mice: A genetic analysis. Animal Behaviour 15:364-76. [RP]

(1968) The confounding effects of genetic variables in early experience research: Can we ignore them? Develommental Psychobiology 1:14652. [NDH]

(1970) Genetic influences on the behavior of mice can be obscured by laboratory rearing. Journal of Comparative and Physiological Psychology 73.505-11. [RP]

(1972) Relative effects of early rearing environment on discrimination learning in house mice. Journal of Comparative and Physiological Psychology 79:243-53. [RP]

(1979a) Adaptive significance of animal behavior: The role of geneenvironment interaction. In: Theoretical advances in behavior genetics, ed. I, R. Royce \& L. P. Mos. Sijthoff \& Noordhoff. [aDW]

(1979b) Repty to comments. In: Theoretical advances in behavior genetics, ed. J. R. Royce \& L. P. Mos. Sijthoff \& Noordhoff. [NDH]

(1982) Human behavior genetics. Annual Review of Psychology 33:40340. [arDW, JH, PM]

(1986) Predicting relationships between psychological constructs and genetic characters: An analysis of changing genetic influences on activity in mice. Behavior Genetics 16:201-20. [NDH, RP]

Henry, K. R. (1986) Audiogenic seizures in relation to genetically and experimentally produced cochlear pathology. In: Perspectives in behavior genetics, ed. J. L. Fuller \& E. C. Simmel. Eribaum. [aDW]

Heth, C. D., Pierce, W. D., Belke, T. W. \& Hensch, S. A. (1989) The effect of logarithmic transformation on estimating the parameters of the generalized matching law. Journal of the Experimental Analysts of Behavior 52:65-76. [aDW]

Hewitt, J. K., Eaves, L. J., Neale, M. C. \& Meyer, J. M. (1988) Resolving causes of developmental continuity of "tracking." 1. Longitudinal twin studies during growth. Behavior Cenetics 18:133-51. [NDH]

IIill, W. G. (1970) Design of experiments to estimate heritability by regression of offspring on selected parents. Biometrics 26.565 71. [rDW]

Hirsch, J. (1981) To "unfrock the charlatans." Sage Race Relations Abstracts 6(2):1-65. [JH, PSH, rDW]

(1970) Behavior-genetic analysis and its biosocial consequences. Seminars in Psychiatry 2:89-105. [JH]

Ho, M.W. \& Fox, S. W., eds. (1988) Evolutionary processes and metaphors. Wiley. [rDW]

Hoaglin, D, C, Mosteller, F. \& Tukey, J. W. ed. (1983) Understanding robust and exploratory data analysis. Wiley. [CG]

(1985) Exploring data tables, trends, and shapes. Wiley. [CG]

Hogben, L. (1939) Nature and nurture. W. W, Norton \& Co., lnc. (Originally published 1933, [JH]

(1951) The formal logic of the nature-nurture issue, Acta Cenetica ef Statistica Medica 2:10L-40. [JH]

Holland, A. J., Sicotte, N. \& Treasure, J. (1988) Anorexia nervosa: Evidence for a genetic basis. Journal of Psychosomatic Research 32:561-71. [PM]

Horn, J. M., Loehlin, J. C. \& Willerman, L. (1979) Intellectual resemblance among adoptive and biological relatives: The Texas adoption project. Behavior Genetics 9:177-207. [RMD]

Hull, C. L. (1945) The place of innate individual and species differences in a natural-science theory of behavior. Psychological Review 52:55 60. [aDW]

Huxley, J. (1932) Problems of Relative Growth. Dover Press, [JMC]

Hyde, J. S. (1973) Genetic homeostasis and behavior: Analysis, data, and theory. Bahavior Genetics 3:233-45. [rDW]
(1981) How large are cognitive gender differences? American Psychologist $36 ; 892-901$. [rDW]

Ingham, P, W. (1988) The molecular genetics of exnbryonic pattem formation in Drosophila. Nature 335:25-34. [rDW]

Jacquard, A. (1983) Heritability: One word, three concepts. Biometrics 39:465-77. [RMD]

Jencks, C. N., Smith, M., Acland, H., Bane, M. J., Cohen, D., Gintis, H, Heyns, B. \& Michelson, S. (1972) Inequality. Harper \& Row. [RMD]

Jensen, A. R. (1980) Precis of bias and mental testing, with commentary. Behatioral and Brain solences 3:325-71, [CG]

Jinks, J. L. \& Broadhurst, P. L. (1974) How to analyse the inheritance of behaviour in animals: The biometrical approach. In: The genetics of behavior, ed. J. H. F. van Abeelen. North-Holland, [aDW]

Jinks, J, L. \& Fulker, D. W. (1970) A comparison of the biometrical genetical, MAVA, and classical approaches to the analysis of human behavior. Psychological Bulletin 73:311-49. [aDW, NDH, JH, PHS]

Judd, C. M. \& MoClelland, G. H. (1989) Data analysis: A model-comparison approach. Harcourt Brace Jovanovich. [SEM]

Kamin, L. J, (1974) The science and politics of IQ. Erlbaum. [RMD, PKIS]

Katz, M. J. (1982) Ontogenetic mochanisms: The middle ground of evolution In: Evolution and development, ed. T. J. Bonner. Springer. [H.PL]

Katz, M. J. Lasek, R. J. (1978) Evolution of the nervous system: Role of ontogenetic mechanisms in the evolutiou of matching populations. Proceedings of the National Academy of Stience USA 75:1349-52. [HPL.]

Keightley, P. D. (1989) Models of quantitative variation of llux in metabolic pathways, Genotics 121:869-976. [JFC]

Kempthome, O. (1952) The design and analysis of experiments. Wiley. $[a D W, O K]$

(1957) An introduction to genetic statistics. Wiley. Reprinted 1969, Iowa State University Press. [OK]

(1978) Logical, epistemological and statistical aspects of naturemurture data interpretation. Biometrics 34:1-23. [OK]

Kendell, R. E. (1982) The choice of diagnostic criteria for biolngical research Archives of General Psychiatry 39:1334-39. [PM]

Kendler, K. S. \& Eaves, L. J. (1986) Models for the joint effect of genotype and environment on liability to psychiatric illness. American Jotmal of Psychiatry 143:279-89. [aDW]

Kennedy, J. L., Giuffra, L. A., Moises, H. W., Gavalli-Sforza, L. L., Pakstis, A. I. Kidd, J. R., Castiglione, C. M., Sjogren, B., Wetterberg, L. \& Kidd, K. K. (1988) Evidence against linkage of schizopbrenia to markers on chromosome 5 in a northem Swedish pedigree. Nature $336: 167-$ 70. [H-PL]

Kenny, D. A. (1957) Statistics for the social and behavioral sciences. Little, Brown. [SEM]

Kerner, A.-L. \& Carson, I. H. (1986) Shiverer*jimpy double mutant mice. I. Biochemical evidence for reciprocal intergenic suppression. Brain Research 374:45-53. [rDW]

Kevles, D. J. (1985) In the name of eugenics. Knopf. [aDW]

Killian, A, M. (1989) Playing dice with the solar system. Sky and Telescope 78 (Aug,): 136 40. [rDW]

Kinsley, C. \& Svare, B. (1987) Genotype modulates prenatal stress effects on aggression in male and fernale mice. Behavional and Nettral Biology 47:139-150. [aDW]

Klein, D. C. \& Yuwiler, A. (1973) $\beta$-adrenergic regulation of indole metabolism in the pineal gland. In: Frontiers in catecholamine research, ed. E. Usdin \& S. H. Snyder. Pergamon Press. [aDW]

Koele, P. (1982) Calculating power in analysis of variance. Psychological Bulletin 92:513-16. [rDW]

Kraemer, H. C. \& Thiemann, S. (1987) How many subjects? Statistical pouter analysis in research. Sage. [aDW]

Kumit, D. M., Layton, W. M. \& Matthysse, S. (1987) Genetics, chance, and morphogenesis. American Journal of Human Cenetics 41:979 95. [rDW]

Kvallseth, T. O. (1985) Cautionary note about $\mathrm{R}^{2}$. American Statistician 39:279-85. [aDW]

Lachenbruch, P. A. (1988) A note on sample size computations for testing interactions. Statistics in Medicine 7:467-69. [aDW]

Lamoreux, M. L. \& Pendergast, P. (1987) Cenetic controls over melanocyte differentiation: Interaction of agouti-locus and albino-locus genetic defects. The Journal of Experimental Zoology 24371-79. [rDW]

Lande, R. (1976) Natural selection and random genetic drift in phetotypic evolution. Evolution 30:314-34. [JMC]

(1979) Quantitative genetic analysis of multivariate evolution, applied to brain: Body size allometry. Evolution 33:402-17. [JMC]

Lassalle, J. M. (1986) Les interactions entre genofype et environment. Psychologie Française 31:205-211. [aDW] 
Lathrope G. M., Lalouel, J. M. \& Jacquard, A. (1984) Path analysis of family resemblance and gene-environment interaction. Biometrics 40:611625. $[\mathrm{aDW}]$

layzer; D. (1974) Heritability analyses of IQ scores: Science or numerology? 1. Sctence 183:1259-66: [RMD]

Jeahy A. M. (1935) Nature-nurture and intelligence. Genetic Psychology Monographs 17(4):236-307. [RMD]

tenke, G, (1988) Unwrapping the genes for myelin. Netron 1:5354. 3. [rDW]

Le Ro, N. L. (1960) Statistische methoden der populationsgenetik. Birkhauser. [RMD]

19606 ) the interpretation of calculated heritability coeflicients with regard to geme and environmental effects as well as to genotype-environment interactions. In: Btometrical genetics, ed. O. Kemptborne.

Pergamon. [RMD]

viu. . R. (1975) Determining sample size for planned and post hoc analysis of variance comparisons, Journal of Educational Measurement 12:99105. [SEM]

Levins, R \& Lewontin, R. (1985) The dialectical biologist. Harvard University Press. [aDW]

Tewontin, - R. (1974) The analysis of variance and the analysis of causes American Journal of Human Genetics 26:400-411. [aDW, DAC]

1982) Organism and environment. In: Learning, development, and culture, ed H, C Plotkin, Wiley, [rDW]

Tichtenstein, G. (1977) Fund backs controversial study of 'racial betterment'. The New York Times, December 11, p. 1. [rDW]

Thidzey G, Loehlin, J., Manosevitz, M. \& Thiessen, D. (1971) Behavioral tenetios Anmual Review of Psychology 22:39-94. [JH]

Lipp. H. - . (1979) Brain complexity enhances speed of behavioral evolution. Behavioral and Brain Sciences 2:42. [H-PL]

1989) Non-mental aspects of encephalisation: The forebrain as a playground of manimalian evolution. Himan Evolution. [H-PL]

17p, I. A. \& Schwegler, H. (1982) Hippocampal mossy fibers and avoidance learning. In: Genetics of the Brain, ed. I. Ljeblich. Elsevier. [H.PL]

Lop H. P, schwegler, H., Crusio, W. E., Wolfer, D. P., Heimrich, B. Driscoll, P. \& Leisinger-Trigona, M.-C. (1989) Using genetically defined rodent strains for the identification of hippocampal traits relevant for twoWry avoidance learning: A noninvasive approach. Experientia 45:84559. [H-PL]

Lipp, H, $\mathrm{P}$ S shwegler, H., Heimrich, B. \& Driscoll, P. (1988) Infrapyramidal mossy fibers and two-way avoidance learning: Developinental Thodification of hippocampal circuitry and adult behavior of rats and mice. The fournal of Neuroscience 8:1905-21. [H-PL]

foellin. J C Willerman, $\mathfrak{L}_{2}$ \& Horn, J. M. (1988) Human behavior 7. genetios. Arinual Review of Psychology 39:101-33. [JH-rDW]

Loevinger, $\mathrm{I}$ ( $(943)$ On the proportional contributions of differences in nature and th worture in differences in intelligence. Psychological Bulletin $40101725-56 .[J \mathrm{H}]$

Tubin, $\mathrm{A}, 1961$ The interpretation of significant interaction. Educational and Psychological Measurement 21:807-817. [aDW]

Syo, M. Barr C. E, Cannon, T. D., Mednick, S. A. \& Shore, D. (1989) Tetal neural development and schizophrenia. Schizophrenia Bulletin 15146,60 , [H-PL]

Mackintosh N. I. (1974) The psychology of a nimal learning. Academic (1ress. [aDW]

Maddox 1. (1984) Genetics and hereditable IQ. Nature 309:579. [JH]

Yagnusson, D, \& Allen, V, L. (1983) An interactional perspective for human devolopment In: Human development: An intermational perspective, ed. 1. Magutusson \& V, L. Allen. Academic Press. [aDW]

Mande) 1 (1961) Non-additivity in two-way analysis of variance. American

Statistical Asociation Journal 56:878-88. [aDW]
[a

Whle, M. K (1980) Likelihood ratio tests of hypotheses: Comments on Pitz's rtitice and some alternative procedures. Psychological Bulletin 87:56874. aDw:

Mratio N O Boomsma, D. I., Neale, M. C. (1989) Foreword. Special issue Win methodology using LISREL. Behavior Genetics 19:5-7. [JH]

17.th, I. C, Eaves; L. J., Kearsey, M. J. \& Davies, P. (1978) The powe

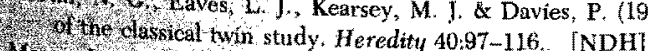

17in) \& Benedito, M. A. C. (1974) Genetic selection of winner and loser

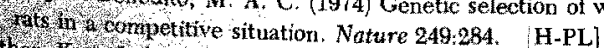

Mither. K. I Jiks, I L. (1982) Biometrical genetics: The study of continuous ratation. Chapman \& Hall. [aDW]

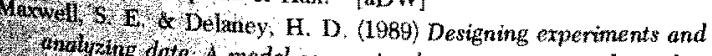

Tay Wuyzing data. A model comparison's perspective. Wadsworth. [SEM]

Moclearn (1960) Genetios and subversion. Nation, May 14, 420-2. [rDW] or, e. Meredith, W. (1960) Behavioral genetics. Annual Review of $x$ s valotogi $7.515-20$, [JH]
MeGue, M., Gottestnan, I. I. \& Rao, D. C. (1983) The transmission of schizophrenia under a multifactorial threshold model. American Journal of Human Genetics 35:1161-78, [H-PL]

(1985) Resolving genetio models for the transmission of schizophrenia. Genetic Epidemiology 2:99-110. [PM]

McGuffin, P., Farmer, A. E., Gottesman, I. I., Murray, R. M. \& Reveley, A. M. (1984) Twin concondance for operationally defined schizophrenia: Confrmation of familiality and heritability. Archives of Genetal Psychiatry 4:1541-45. [PM]

McGuffin, P., Katz, R. \& Aldrich, J. (1986) Past and present state examination: The assessment of "lifetime ever" psychopathology. Psychological Medicine 16:461-65. [PM]

McGuffin, P, Katz, R. \& Bebbington, P. (1988) The Camberwell collaborative depression study III. Depression and adversity in the relatives of depressed probands. British Joumal of $P_{\text {sychiatry } 152: 775-}$ 82. [PM]

McGuire, T. R. \& Hirseh, J. (1977) General intelligence ( $\mathrm{g}$ ) and heritability $\left(\mathrm{H}^{2}, \mathrm{~h}^{2}\right)$. In: The structuring of experience, ed. 1. C. Uzgiris \& $\mathrm{F}$. Weizmann. Plenum. [aDW, JH]

Meehl, Paul E. (1978) Theoretical risks and tabular asterisks: Sir Karl, Sir Ronald, and the slow progress of solt psychology. Journal of Consulting and Clinical Psychology 46;806-34. [JH]

Moisset. B. (1977) Factors contributing to the modulation of norepinephrine uptake by synaptosomes from mouse brain cortex. Brain Research 121:113-20. [rDW]

Moran, P. A. P. (1968) An introduction to probability theory. Clarendon Press. [JFC!

Nanney, D. L. (1986) Eugenies and human heredity. The Joumal of Heredity 77:481-82. [rDW]

Nave, K.-A., Bloom, F. E. \& Milner, R. J. (1987) A single nucleotide difference in the gene for myelin proteolipid protein defines the fimpy mutation in mouse. Journal of Neurochemistry 49:1873-77. [rDW]

Newman, H. H., Freeman, F. N. \& Holzinger, K. J. (1937) Twins: A study of heredity and entironment. University of Chicago Press. [RMD, PHS]

Neyman, J. (1935) Comments on Mr. Yates ${ }^{*}$ paper. Journal of the Royal Statistical Society, Supplement 2:235-41. [aDW, OK]

Nordskog. A, W. (1977) Sucess and falure of quantitative genetic theory in poultry. In: Rroceedings of the International Conference on Quantitatioe Genetics, ed. E. Pollak, O. Kempthorne \& T. B. Batley, Jr. Iowa State University Press, [rDW]

Norton, D. W. (1952) An empirical investigation of some effects of non normality and heterogeneity of the Frdistribution. Doctoral dissertation, State University of Iowa. [DAC]

Nosten, M. (1989) Early development in mice VI. Additive and interactive effects of offspring genotype and maternal environments. Physiology and Behavior 45955-61. [MC]

Nosten, M. \& Roubertoux, P. L. (1988) Uterine and cytoplasmic effects on pup eyelid opening in two inbred strains of mice, physiology and Behatior 43:167-71. [MC]

Nyborg, H. (1977) The rod-and-frame test and the field dependence dimension: Some methodological, conoeptual, and developmental considerations. Dansk Psykologisk Forlag: [HN]

(1983) Spatial ability in men and women: Review and new theory. Advances in Behavior Research and Therapy (Monograph Series) 5(whole no. 2): $89-140$. [HN]

(1984) Performance and intelligence in hormonally-different groups. In: Sex differences in the brain: The relation between structure and function, ed. G. J. De Vries, J. P. C. de Brin, H. B. M. Uylings \& M. A. Corner. Progress in Brain Research, vol. 61. Elsevier Biomedical Press. [HN]

(1987) Individual differences or different individuals? That is the question. Behavioral and Brain Sciences 10:34-35. [HN]

(1988) Mathematios, sex hormones, and brain function. Behavioral and Brain Sciences 11:206-7. [HN]

(1989) Sex hormones, brain development, and spatio-perceptual strategies in women with Turner's syndrome and in school girls. In Sex chromosome abnormalities and behavior: Psychological studies, ed. B. Bender \& D. Berch. Westview Press. [HN]

(submitted a) Sex, body, mind, and society: A physicological approach [HN]

(submitted b) Nonlinear harmonization of body, bram, and intellectual development: A model, a theory, and a research program. [HN]

Nyborg, H. \& Boeggild, C. (1989) Origin of individual and sex differences in body and ability. Paper presented at the fourh meeting of the International Society for the Study of Individual Differences. Federal Republic of Germany, June 22-25. [HN]

Oliverio, A., Eleftheriou, B. E. Balley, D. W. (1973) Exploratory activity; 
Genetic analysis of its modification by scopolamine and amphetamine. Physiology and Behavior 10:893-99. [rDW]

Oyama, S. (1985) The ontogeny of information. Cambridge University Press, [aDW, DD]

(1988) Reply to Robert Plomin's review of The ontogeny of information. Developmental Psychobiology 21:97-100. [aDW]

Palmer, A. R. \& Strobeck, C, (1986) Fluctuating asymmetry: Measurement analysis, patterns. Annual Review of Ecology and systematics 17:391421. [rDW]

Parsons, P. A. (1988) Behavior, stress and variability. Behavior Genetics 18:293-308. [NDH]

Pearson, K. A. (1930) Tables for statisticians and biometricians, Cambrilge University Press. [GMH]

Peeler, D. F. (1986) Circadian variations in activity of neuroanatomically distinct recombinant inbred mice as a function of genetic and measurement variables, Society for Neuroscience Abstracts 12:1069. [rDW]

Peeler, D. F. \& Nowakowski, R. S. (1987) Active avoidance performance in genetically defined mice. Behavioral and Netural Biology 48:8389. $[\mathrm{rDW}]$

Perkins, J. M. \& Jinks, J. L. (1973) The atsessment and specificity of environmental and genotype-environmental components of variability. Heredity 30:111-126. [aDW]

Peters, D. P. \& Ceci, S. J, (1982) Peer review practices of psychological journals: The fate of articles, submitted again. Behacioral and Brain Scienes 5:187-255. [PHS]

Phillips, K., Fulker, D. W. \& Rose, R. J. (1987) Path analysis of seven fear factors in adult twin and sibling pairs and their parents. Cenetic Epidemiology 4:345-55. [aDW]

Fike, W. L. (1978) Short-term instruction, test-wiseness, and the Scholastic Aptitude Test. College Entrance Examination Board. [PHS]

Flatt, S. A. \& Sanislow, C. A., 111 (1988) The norm-of-reaction: Definition and misinterpretation of animal research. Journal of Comparative Psychology 102:254-61. [aDW]

Plomin, R. (1989) Developmental behavior genetics. Child Development $54: 253-59$. [RMD]

(1986) Development, genetics and psychology. Erlbaum. '[aDW, DKD, AL.

(1988) Reply to Susan Oyama's review of Development, genetics and Psychology. Development Psychobiology 21:107-12. [aDW, RL]

Plomin, R. \& Daniels, D. (1987) Why are children in the same family so different from one another Behavioral \& Brain Sciences 10:160. [WEC, $\mathrm{DDW}]$

Plomin, R. \& DeFries, J. C. (1983) The Colorado adoption project. Child Development 54:276-89. [aDW]

Plomin, $\mathbf{R}_{*}$, Defries, J. C. Fulker, D. W. (1988) Nature and nurture during infancy and early childhood. Cambridge University Press. [RL]

Plomin, R., DeFries, J. C. \& Loehlin, J. C. (1977) Genotype-environment interaction and correlation in the analysis of human behavior. Psychological Bulletin 84:309-22. [aDW, RMD, JH, RL]

Plomin, R., DeFries, J. C. \& McCleam, G. E. (1980) Behavioral genetics, a primer. Freeman. [aDW, WEC, RL]

Plomin, R., Loehlin, J, C. \& DeFries, J. C. (1985) Genetic and environmental components of "environmental" intluences. Developmental Psychology 21:391-402. [aDW]

Poston, T. \& Stewart, 1, (1978) Catastrophe theory and its applicatons. Pitman Publishing, Ltd [FLB]

Powers, L. (1950) Determining scales and the use of transformations in studies of weight per locule of tomato fruit. Biometrics $6: 145-$ 63. [GMH]

(1955) Components of variance method and partitioning method of genetic analysis applied to weight per fruit of tomato hybrid and parental population. Bulletin 1131 of the U.S. Department of Agriculture. [GMH]

Press, W. H., Flannery, B. P., Teukolsky, S. A. \& Vetterling, W. T. (1988) Numerical recipes in $C$. Cambridge University Press [rDW]

Pritchard, D. I. (1986) Foundations of developmental genetics. Taylor \& Francis. [aDW, HN]

Provine, W. 1971) The origins of theoretical population genetics. University of Chicago Press. [JMC]

Reid, J. B. \& Murfet, I C. (1977) Flowering in Pistm: The effect of light quality on the genotype if e Sn Hr. Journal of Experimental Botany $28: 1357-64$. [rDW]

Reik, W., Collick, A., Norris, M. L., Eurton, S. C. \& Surani, A. (1987) Genomic imprinting determines methylation of parental alleles in transgenic mice. Nature 328:248-51. [rDW]

Ricker, J. P. \& Hirsch, ], (1988) Reversal of genetic homeostasis in laboratory populations of Drosophila melanogaster under long-term selection for geotaxis and estimates of gene correlates: Evolution of behavior genetic systems. Jotrnal of Comparative Psychology 102:203-14. [rDW]

Riska, B. (1986) Some models for development, growth, and morphometric correlation. Evolution 40:1303-11. [JMC]

Roberts, D. W. A. \& Larson, R. I. (1985) Vernalization and photoperiodic responses of selected chromosome substitution lines derived from Rescue, Cadet, and Cypress wheats. Canalian joumal of Genetics and Cytology 27:586m91. [rDW]

Rosenthal, R. \& Rosnow, R. L. (1985) Contrast analysis: Focused comparisons in the analysts of variance. Cambridge University Press. [SEM]

Rotton, J. \& Schönemann, P. H. (1978) Power tables for the analysis of variance. Educational and Pychological Masurement 38:21329. [rDW]

Rouanet, H., Lepline, D. \& Holender, D. 1978) Model acceptability and the use of Bayes-fiducial methods for validating models. In Attention and Performance VII, ed, ]. Requin. Erlbaum. [MC]

Rouanet, H., Lecoutre, B. (1983) Specific inference in ANOVA: From significance tests to Bayesian procedures. British Journal of Mathematical and Statistical Psychology 36:252-68. [MC]

Roubertoux, P. L. (1981) Valeur explicative du concept dinteraction en analyse génétique. Les Niveatux dExplication an Psychologie. Colloque CNRS. $[\mathrm{MC}]$

Roubertoux, P. L., Nosten-Bertrand, M. \& Carlier, M. (in press) Additive and interactive effects between genotype and environment: Concepts and facts. Advances in the Study of Behavior. [MC]

Roux, C. Z. (1984) Treatment $x$ unit interactions in the completely randomized and randomized block designs, 1n: Experimental design, statistical models, and genetic statistics, ed. K. Hinkelmann. Marcel Dekker. [aDW]

Rowe, D. C. (1987) Resolving the person-situation debate. American Psuchologist 42:218-27. [aDW]

Rutherford, J., Katz, R. \& McGuffin, P. (in preparation) Genes, environment, and attitudes to eating. [PM]

Salsburg, D. 5. (1985) The religion of statistics as practiced in medical journals. The American Statistician 39:220-23. [rDW]

Sapienza, C., Peterson, A. C., Rossant, J. \& Balling, R. (1987) Degree of methylation of transgenes is dependent on gamete of origin. Nature $328: 251-54$. [rDW]

Satinder, K. P. \& Sterling, J. W. (1983) Differential effects of pre- and/or post-natal $d$-amphetamine on avoidance response in genetically selected lines of rats. Neurobehavioral Toxicology and Teratology 5:315 20. [rDW]

Scarr, S. \& Weinberg, R. A. (1976) 10 test performance of black children adopted by white families. American psychologist 31:726-39. [RMD]

Scharloo, W. (1989) Developmental and physiological aspects of reaction norm. BioScience 39:465-71. [AJVN]

Scheffe, H. (1959) The analysis of variance, Wley. [aDW, PHS]

Schiff, M., Duyme, M., Dumaret, A., Stewart, J., Tomkiewicz, S. \& Feingold, J. (1978) Intellectual status of working-class children adopted early into upper middle class families. Science 200:1503-4. [RMD]

Schlichting, C. D. (1989) Phenotypic integration and environmental change. Biosctence 39:460-64. [AJVN]

Schmalhausen, 1, 1. (1949) Factors of evolution. Blakiston. Reprinted 1986 by University of Chicago Press. [aDW]

Schneider, K. (1959) Clinical psychopathology. Translated by M. W Harnilton. Grune and Stratton. [PM]

Schönemann, P. H. (1981) Power as a function of communality in factor analysis. Bulletin of the Psychonomic Society 17:57-60. [PHS]

(1987) Letter to J. Hirsch, November 30, 1987. In J. Hirseh papers, University of Illinois Archives, No. 15/19/22. [JH]

(1989a) New questions about old heritability estimates. Bulletin of the Psychonomic Society 27:175-78. [PHS]

(1989b) Some new results on the Spearman hypothesis artifact. Bulletin of the Psuchonomic Society. [PHS]

Schulsinger, F., Parnas, J., Mednick, S., Teasdale, T. W. \& Schulsinger, H. (1987) Heredity-environment interaction and schizophrenia. Joumal of Psuchiatric Research 21:431-36. [rDW]

Scott, J. P. (1942) Genetic differences in the social behavior of inbred strains of mice. The Joumal of Heredity 33:11-15. [rDW]

Sedlmeier, P. \& Gigerenzer, G. (1989) Do studies of statistical power have an effect on the power of studies? Psychological Bulletin 105:30916. [SEM]

Severo, N. C. \& Zelen, M. (1960) Normal approximation to the chi-square and non-central F probability functions. Biometrika 47:411-16. [aDW]

Shields, J. (1960) Monozygotic twins brought up apart and brought up together. Oxford University Press. [PHS]

Shockley, W. (1987) Jensen's data on Spearman's hypothesis: No artifact. Behavioral and Brain Sciences 10:512. [PHS] 
Strol E. C. \& Eletherion, B. E. (1977) Multivariate and behavior genetic and of complex visual stimuli and activity in recombinan ibred strains of mice. Behavior Genetict 7:239-50. [rDW]

a 1 Skeels, H. M. (1949) A final followup study of one hundred adopted children. Journal of Genetic Psychology 75:85-125. [RMD] W 1 \&orter, D. (1980) The Scholastic Aptitude Test: A critical W appraisal. Harvard Educational Raview 50:154-75. [PHS]

th $\mathrm{M}$ (1987) Quantitative geneties of heterochrony. Evolution 41:79981]. [JMC]

totherman, W. P. \& Robinson, S. R. (1988) Behavitor of rat fetuses following chemical or tactile stimulation. Behavioral Newroscience $102: 24-34$. [rDW]

Fedecor, o, W. \& Cochran, W. G. (1980) Statisticol methods. Lowa State Unversity Press. [CG]

067 Stitistical methods. Lowa State University Press, [PHS]

per H, V, Cíchetti, D. V., Satz, P., Light, R. \& Orsini, D. L. (1988) Vull hypothesis disrespect in neuropsychology: Dangers of alpha and beta eror. Journal of Clinical and Experimental Netropsychology 10:25570. IDVG

tearns, $\&, C$. (1989) The evolutionary signifieance of phenotypic plasticity. Bwostance 39:436-446. [AJV N]

tent, $\mathrm{C}, \mathrm{S}, \mathrm{1}$ (1981) Strength and weakness of the genetic approach to the development of the nervous system. Annual Review of Neuroscience 4.163-94, [aDW]

4ten (6.) (1988) Biological science and the roots of Nazism. American 7. Scientist 76:50-58." [rDW]

Tand $\mathrm{F}, \mathrm{C}, 1938$ ) The power finction of the analysis of variance tests with tables and lliustrations of their use. Siatistical Research Menoirs 2:12657. [aDW]

Fylor $\mathrm{E}, \mathrm{E} \&$ Condra, C. (1978) Genetic and environmental interaction in Drosphila pseudoobscuta. Joumal of Heredity 69:63-64. [RP] Taylor. $1, \mathrm{~F}$ (1980) The $1 \mathrm{Q}$ game. Rutgers University Press. [rDW] Thina, P Som, A., Lahti, I, Naarala, M., Wahlberg, K.-E., Moring, J., Tohola I, \& Wynne, L. C. (1987) Genetic and psychosocial factors in schzophrenia. The Finnish adoptive family study. Schirophrenia Bulletin $13.47784 .[\mathrm{rDW}]$

Tiki, $\mathrm{M} 1$ (1966) A note on approximating to the noncentral F distribution. Blometrika 53:606-10. [aDW]

197) Power function of the F-test under non-normal situations. Journal of The hnerican Statistical Association 66:913-16. [DAC]

Towisend, T, Ashby, F, G, (1984) Measurement scales and statistics The misconception misconceived. Psychological Bulletin 96:394301. $[\mathrm{aDOW}$

Trailer, R 4 (1976) A snag in the history of factorial experiments. In: On the history of statistics and probability, ed, D. B. Owen. Marcel Dokker [aDW. DVC]

Tukify 1 w 1957 On the comparative anatomy of transformations. Annals of Wathematical statistics $28: 602-32$. [aDW]

Van Abelen, J, H.F, Van der Kroon, P. H. \& Bekers, M. F. (1973) Mice selected for rearing behavior: Some physiological variables. Behavior Coneros $3(1), 85-90$. [H-PL]

Vad Noordwik, a, (1989) Reaction thorms in genetical ecology. Bioscience $30453-50$, [AJVN]

Vouortmerssen, G. A Bakker, T. C. (1981) Artificial selection for short and Iong attack latencies in wild Mus musculus domesticus. Behacior Gentes $11(2) 115,26,[\mathrm{H}-\mathrm{PL}]$

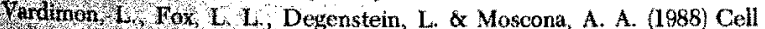
contats are teguined for induction by cortisol of glutamine synthetase 8cone transcription in the retina. Proceedings of the National Academy of Scteroe U. 8,8 85:5981-85. [rDW]

Vet. 1 10sd Appendix lin. J. Hirsch, To "unfrock the charlatans." Sage Race nalatons Abstacts 6:35-39. [aDW, PHS]
Via, S. (1984a) The quantitative genetics of polyphagy in an insect herbivore. I. Genotype-enviromment interaction in larval performance on different host plant species. Evolution 38:881-95. [C]G]

(1984b) The quantitative genetics of polyphagy in an insect herbivtre. 11. Genetic correlations in larval performance within and among host plants. Evolution 36:896-905. [CIG]

Via, S. \& Lande, R. (1985) Genotype-enviroument interaction and the evolution of phenotypic plasticity. Evolution 39:505-22. [aDW, JMC, GJG]

Wachs, T. D. (1983) The use and abuse of environment in behavior-genetic research. Child Development 54:396-407, [rDW]

Wahlsten, D. (1978) Behavioral genetics and animal learning. In: Rychopharmacology of acersitely motivated behavior, ed. H. Anisman \& G. Bignami. Plenum. [rDW]

(1979) A critique of the concepts of heritability and heredity in behavioral genetics. In: Theoretical advances in behavior genetics, ed. I. R. Royce \& L. P. Mos. Sijthoff \& Noordhoff, [aDW, NDH]

(1983) Maternal effects on mouse brain weight. Developmental Brain Research 9:216-21. [rDW]

1987a) Insensitivity of analysis of variance to heredity-environment interaction. Paper presented at the Behavior Genetics Association amual meeting, Minneapolis, June 27. [rDW]

(1987b) Three sources of individual differences. Paper presented at the Canadian Psychological Association annual meeting, Vancouver, June, [rDW]

1989a) Genetic and developmental defects of the mouse corpus callosum. Experientia.45:828-38. [rDW]

(1989b) Sample size and power to detect a linear contrast, with application to interaction in a $2 \times 2$ design. Unpublished manuseript. [rDW]

Wainwright, P. (1980) Relative effects of matemal and pup heredity on postnatal mouse development. Developmental Psychobiology 13:493-98. [rDW]

Ward, R. (1985) Genetic polymorphisms and additive genetic models. Behavior Genetics 15:537-48. [rDW]

Wilson, L. M. \& Sinha, I. L. (1985) Thermal preference behavior of genetically obese $(o b / o b)$ and genetically lean $(+/ P)$ mice. Physiology and Behavior 35:545-58. [rDW]

Wimer, R. E. Wimer, C. C. (1982) A biometrical-genetic analysis of granule cell number in the area dentata of house mice. Developmental Brain Research 2:129-40. [nDW]

Winer, B. J. (1971) Statistical principles in experimental design, 2nd ed. McGraw-Hill, [aDW]

Winslow, G. M., Carroll, S, B. \& Scott, M. P. (1988) Maternal-effect genes that alter the fate map of the Drosophila blastoderm embryo. Developmental Biology 129:72-83. [nDW]

Wittgenstein, L. (1953) Philosophical investigations. Macmillan. [DB]

Wright, S. (1921) Correlation and causation. Journal of Agricultural Research $20.557-85$. [aDW]

(1934) The method of path coefficients. Annals of Mathematical Statistics 5:161-215. [GMH]

1978) The relation of livestock breeding to theories of evolution. Journal of Antmal Science 46:1102-1200. [rDW]

Yates, F. (1935) Complex experiments. Journal of the Royal Statistical Society, Supplement 2:181-223. [aDW]

Yeakley, J. M., Janavs, I. L. \& Reiness, C. G. (1957) Muscle activity pattem regulates postratal development of acetylcholinesterase molecular forms in normal mice and mice with motor endplate disease. The Joumal of Neuroscience 7:4084-94. [rDW] .

Zacharko, R. M., Lalonde, G. T., Kasian, M. \& Anisman, H. (1987) Strainspecific effects of inescapable shock on intercranial self-stimulation from the nucleus accumbens. Brain Research 426:164-68. [rDW] 